\title{
QUANTIFYING CHLORIDE RETENTION IN URBAN STORMWATER MANAGEMENT PONDS USING A MASS BALANCE APPROACH
}

By

\author{
Wai Ying Lam \\ B.Sc. Honours Biology and Environmental Sciences, McMaster University, 2017
}

\author{
A thesis \\ presented to Ryerson University \\ in partial fulfillment of the requirements for the degree of \\ Master of Applied Science \\ in the program of \\ Environmental Applied Science and Management
}

Toronto, Ontario, Canada, 2019

(C) Wai Ying Lam, 2019 


\section{Author's Declaration}

\section{AUTHOR'S DECLARATION FOR ELECTRONIC SUBMISSION OF A THESIS}

I hereby declare that I am the sole author of this thesis. This is a true copy of the thesis, including any required final revisions, as accepted by my examiners.

I authorize Ryerson University to lend this thesis to other institutions or individuals for the purpose of scholarly research.

I further authorize Ryerson University to reproduce this thesis by photocopying or by other means, in total or in part, at the request of other institutions or individuals for the purpose of scholarly research.

I understand that my thesis may be made electronically available to the public. 


\section{Abstract}

Quantifying chloride retention in urban stormwater management ponds using a mass balance approach

Wai Ying Lam

M.A.Sc., 2019

Environmental Applied Science and Management

Ryerson University

Chloride $\left(\mathrm{Cl}^{-}\right)$from runoff containing deicing salts is retained in watersheds after deicing ends, resulting in deleterious effects on aquatic biota. Stormwater management ponds (SWMPs) are known to impact pollutant transport. However, there is little information on what role SWMPs play in the timing and magnitude of $\mathrm{Cl}^{-}$transport in urban watersheds. This study quantifies the mass of $\mathrm{Cl}^{-}$retained in two urban SWMPs over varying timescales and the in-stream response to $\mathrm{Cl}^{-}$-laden pond outflows.

The findings suggest that SWMPs likely play a role in watershed-scale $\mathrm{Cl}^{-}$retention. In the receiving creek, $\mathrm{Cl}^{-}$pulses corresponded to $\mathrm{Cl}^{-}$release from the pond. The results of this study suggest that SWMPs concentrate spatially distributed salt inputs and modify the timing and magnitude of their release to receiving streams. This study will help parameterize the role of SWMPs in watershed-scale $\mathrm{Cl}^{-}$transport models and geospatial models of salt vulnerable areas. 


\section{Acknowledgements}

I would like to thank...

...first and foremost, my supervisor and mentor, Dr. Claire Oswald, for her insight, ideas, and unwavering support throughout this work. Her enthusiasm and willingness to provide encouragement have been a tremendous motivation to make the following research possible.

...committee members Drs. Chris Wellen and Darko Joksimovic for their technical insight regarding the study design and analyses, and for reviewing this thesis.

...our study partners at Lake Simcoe Region Conservation Authority, David Lembcke and Chandler Eves, for their technical insight and data support.

...my long-time lab and field partner, Kayla Wong, for commiserating with me when things went wrong and celebrating with me when even the smallest thing went right.

...the members of the Ryerson Watershed Hydrology and Biogeochemistry Research Group, Arsh Grewal, Krystal Siebert, Sarah Ariano, Bhaswati Mazumder, and Ela Lichtblau, for their constructive suggestions and technical support.

...Ryerson University, the Yeates School of Graduate Studies, and the EnSciMan Program Council for their financial support.

...finally, my family and friends for their love and support through the years. 


\section{Table of Contents}

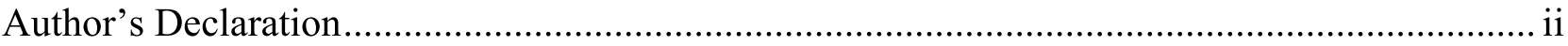

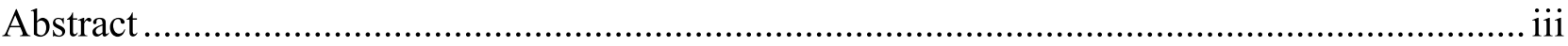

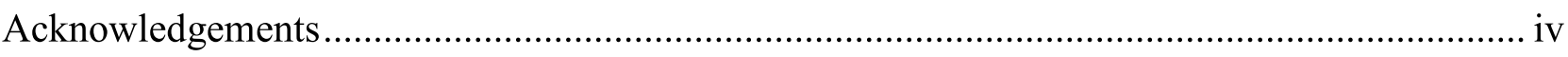

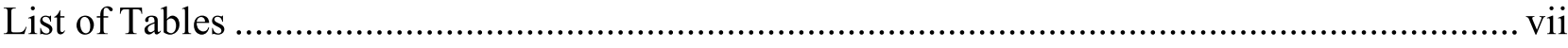

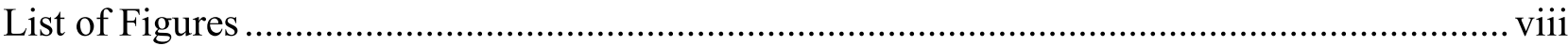

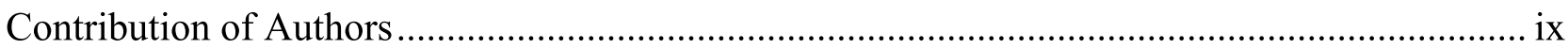

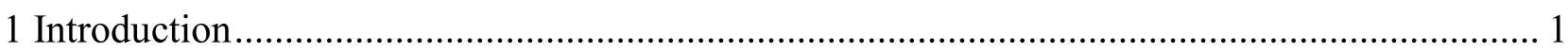

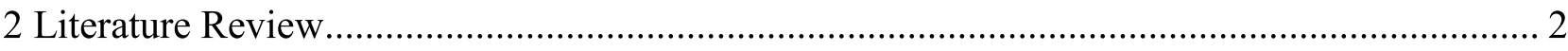

2.1 Overview of Urban Hydrology ................................................................................... 2

2.2 Impacts of Urbanization on Water Quantity ………….................................................... 3

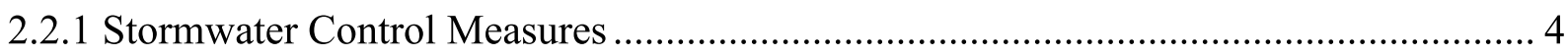

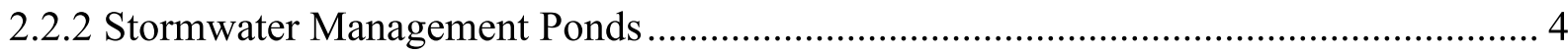

2.3 Impacts of Urbanization on Water Quality ………….................................................... 5

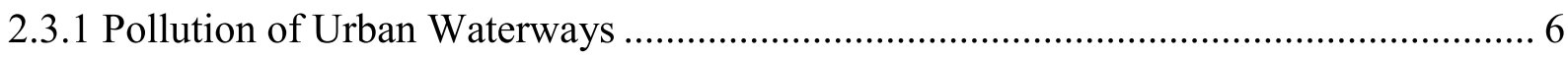

2.3.2 Water Quality in Stormwater Management Ponds .......................................................... 6

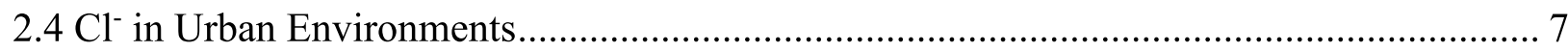

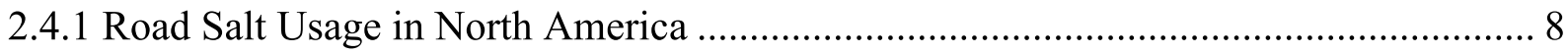

2.4.2 $\mathrm{Cl}^{-}$Transport Through Urban Watersheds............................................................ 9

2.4.3 Long-Term $\mathrm{Cl}^{-}$Concentration Trends in Freshwater Systems ................................... 12

2.4.4 Effects of Elevated $\mathrm{Cl}^{-}$on Freshwater Systems ...................................................... 13

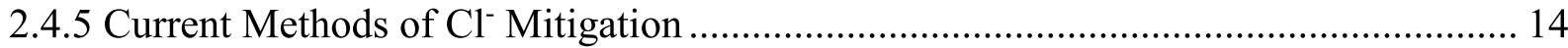

3 Quantifying Chloride Retention in Urban Stormwater Management Ponds Using a Mass

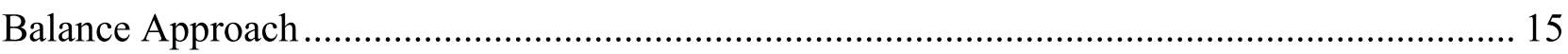

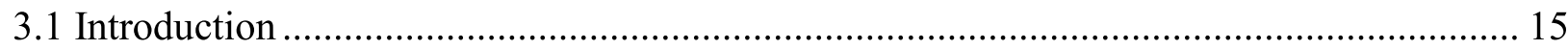

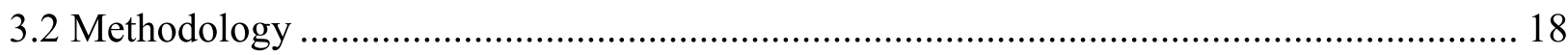

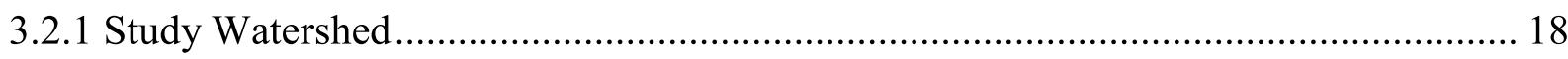

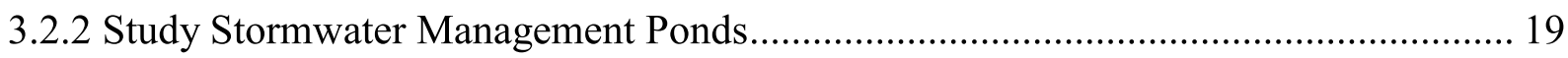

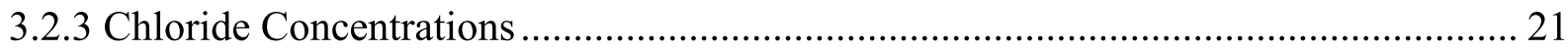

3.2.4 Water Balance and $\mathrm{Cl}^{-}$Mass Balance Calculations.................................................... 23

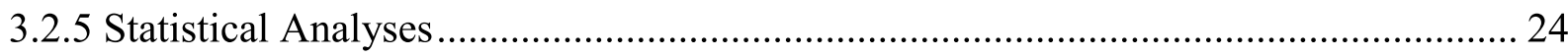




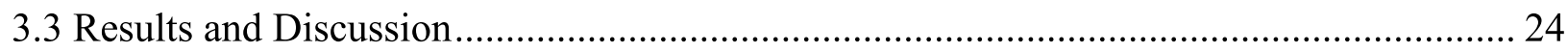

3.3.1 Annual and Seasonal Variability in SWMPs' Water Balances .................................. 24

3.3.2 Annual and Seasonal Variability in SWMPs' $\mathrm{Cl}^{-}$Mass Balances ................................ 27

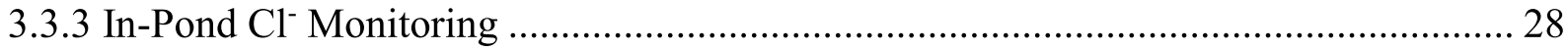

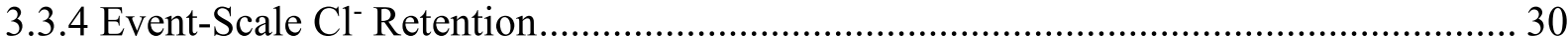

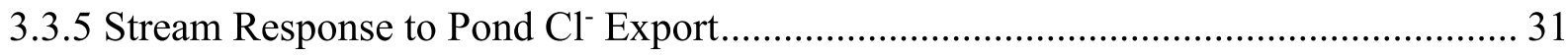

3.3.6 Implications for Understanding the Influence of SWMPs on Watershed-Scale $\mathrm{Cl}^{-}$

Retention and the Identification of SVAs............................................................................. 33

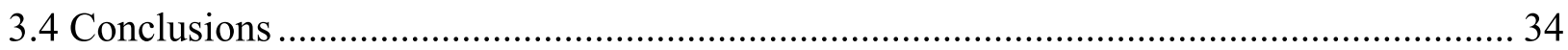

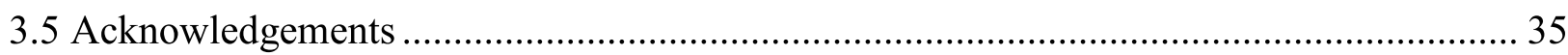

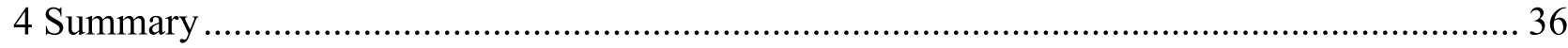

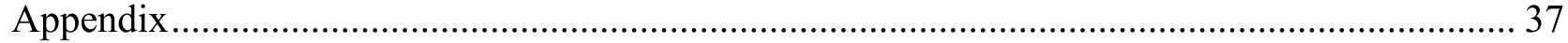

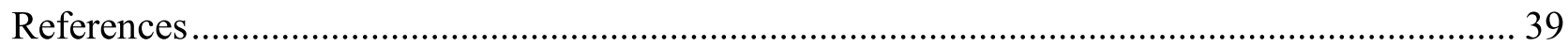




\section{List of Tables}

Table 1. Water balance for $\mathrm{DH}$ and $\mathrm{OAK}$ for each season and year of the study period $(\mathrm{W}=$ winter, November - April; $\mathrm{S}=$ summer, May - October; Y = year, November - October). All units in $100,000 \mathrm{~L}$. I = input, $\mathrm{P}=$ precipitation, $\mathrm{E}=$ evaporation, $\mathrm{O}=$ output, $\mathrm{S}=$ storage (retention).

Table 2. $\mathrm{Cl}^{-}$balance for $\mathrm{DH}$ and $\mathrm{OAK}$ for each season and year of the study period. All units in tonnes. $\mathrm{I}=$ input, $\mathrm{O}=$ output, $\mathrm{A}=$ adjustment, $\mathrm{S}=$ storage (retention). 


\section{List of Figures}

Figure 1. EHR watershed boundary relative to Lake Simcoe. Inset maps are OAK (upper) and DH (lower) and their contributing catchments, indicated by the directly connected impervious area (DCIA) and study pond topographic boundaries.

Figure 2. Water and $\mathrm{Cl}^{-}$balances for DH ((a) and (c)) and OAK ((b) and (d)) for each season of the study period ( $\mathrm{W}=$ winter, November - April; $\mathrm{S}=$ summer, May - October). For water balances ((a) and (b)), inputs are inflows and precipitation; outputs are outflows and evaporation. $\mathrm{I}=$ input, $\mathrm{O}=$ output, $\mathrm{S}=$ storage (retention). Hatched lines indicate the adjustment applied to the outflow; the bolded outline indicates the outflow used to determine $\mathrm{Cl}^{-}$storage. Note that (i) negative retention indicates release, and (ii) y-axes differ between ponds.

Figure 3. $\mathrm{Cl}^{-}$concentrations in the (a) forebay and (b) wet cell of DH over a 2-year period. Data unavailable in wet cell between Nov ' 16 and Feb '17. Note the different y-axis ranges. 29

Figure 4. Percentage of $\mathrm{Cl}^{-}$retained by (a) DH and (b) OAK during rain and melt events in the 2 -year pond monitoring period $(\mathrm{n}=201)$. Note that negative retention indicates $\mathrm{Cl}^{-}$ release.

Figure 5. (a) Stream $\mathrm{Cl}^{-}$response to the pond outflow at OAK. Lower and upper lines represent chronic and acute CWQG for the protection of aquatic life, respectively. (b) The recorded mass of $\mathrm{Cl}^{-}$leaving $\mathrm{OAK}$ for each 15-minute interval in the stream monitoring period

Figure 6. Level-to-flow plots for the (a) DH inflow $\left(\mathrm{R}^{2}=0.73\right)$, (b) $\mathrm{DH}$ outflow $\left(\mathrm{R}^{2}=0.99\right)$, (c) OAK inflow $\left(\mathrm{R}^{2}=0.99\right)$, and (d) OAK outflow $\left(\mathrm{R}^{2}=0.98\right)$. 


\section{Contribution of Authors}

The manuscript included herein has three authors: Wai Ying Lam (Ryerson University), David Lembcke (Lake Simcoe Region Conservation Authority), and Claire Oswald (Ryerson University).

W.Y. Lam, D. Lembcke, and C. Oswald all contributed to the initial design of the study. W.Y. Lam and C. Oswald made some adjustments to this design over the study period.

W.Y. Lam was responsible for collecting and filtering grab samples as well as calibrating and deploying inlet, outlet, and stream data loggers and consolidating the raw data. D. Lembcke was responsible for deploying in-pond data loggers as well as the inlet and outlet weir and flow loggers and consolidating the raw data.

Data analysis and interpretation were carried out by W.Y. Lam. Text, tables, and figures were drafted by W.Y. Lam and critically reviewed by C. Oswald and D. Lembcke.

W.Y. Lam, D. Lembcke, and C. Oswald all approved of the final version to be published. 


\section{Introduction}

It is widely known that increasing urban development, accompanied by increased impervious area, has negative impacts on streams. In urban areas that experience cold winters, chloride $\left(\mathrm{Cl}^{-}\right)$is a pollutant of note. $\mathrm{Cl}^{-}$in urban waterways is largely derived from runoff containing deicing salts applied to maintain safe driving conditions (Novotny and Stefan, 2010; Perera et al., 2010; Oswald et al., 2019). It can have deleterious effects on aquatic biota and may pose a threat to drinking water (Walsh et al., 2012; Kaushal, 2016; Wallace and Biastoch, 2016).

$\mathrm{Cl}^{-}$can accumulate in freshwater systems for extended periods; therefore, the negative impacts of elevated $\mathrm{Cl}^{-}$concentrations can be observed beyond the winter deicing period (Chapra et al., 2009; Winter et al., 2011).

One common method employed by municipalities to mitigate changes to natural water quantity and quality is the installation of stormwater management ponds (SWMPs) (LSRCA, 2011; TRCA, 2012). However, there is a paucity of information on what role SWMPs play in the timing and magnitude of $\mathrm{Cl}^{-}$export from urbanizing and urban watersheds. In this study, a mass balance approach is employed to quantify $\mathrm{Cl}^{-}$retention in two SWMPs located in an urbanizing watershed in south-central Ontario. This research aims to address the role that urban SWMPs play in the timing and magnitude of $\mathrm{Cl}^{-}$transport by (1) quantifying the mass of $\mathrm{Cl}^{-}$entering and leaving a pair of SWMPs; (2) determining annual, seasonal, and event-scale $\mathrm{Cl}^{-}$retention for the SWMPs using a mass balance approach; (3) comparing changes in $\mathrm{Cl}^{-}$retention to in-pond $\mathrm{Cl}^{-}$ concentrations; and (4) quantifying the response of a receiving stream to $\mathrm{Cl}^{-}$exported from a SWMP. It will inform the parameterization of the role of SWMPs in watershed-scale $\mathrm{Cl}^{-}$models, as well as the identification of Salt Vulnerable Areas. 


\section{Literature Review}

This review will briefly describe urban impacts on hydrology and explain how stormwater control measures impact water quantity and water quality. It will then delve into $\mathrm{Cl}^{-}$ in urban environments and provide a background on $\mathrm{Cl}^{-}$transport through SWMPs. Lastly, it will discuss trends and effects of $\mathrm{Cl}^{-}$in freshwater systems.

\subsection{Overview of Urban Hydrology}

Urban development has three main impacts on urban hydrology: increased total runoff, altered peak flow characteristics, and compromised water quality (Anderson, 1970). These impacts arise from current urban water management practices, which aim to move storm- and wastewater away from urban areas as efficiently as possible (Mitchell et al., 2001).

Urban development results in increased imperviousness, which restricts the infiltration of water into the ground (Davis and McCuen, 2005). This produces greater surface runoff volumes. Often, stream channels are straightened and streambeds are altered to increase hydraulic capacity and prevent erosion (Marsalek et al., 2006). Transportation corridors, such as roadways and accompanying storm sewers, ditches, and culverts, efficiently direct overland flow into these channelized streams, and the overall speed of runoff is increased (Meierdiercks et al., 2010a). Overall, urban areas have reduced water storage capacity and generate more runoff, which travels more quickly, than natural areas. 
Greater surface runoff and reduced natural water storage in urban environments also facilitate the transport of urban pollutants to freshwater systems (Walsh et al., 2012). Common pollutants include but are not limited to oil and grease from vehicles, $\mathrm{Cl}^{-}$from road salt, nutrients from fertilizers, and elevated water temperature due to the urban heat island effect (Walsh et al., 2012; Ehrenfeld et al., 2015; Booth et al., 2016).

\subsection{Impacts of Urbanization on Water Quantity}

Urban drainage systems, which may include structures such as stormwater pipes, street gutters, roadside swales, other surface channels, and stormwater management ponds, play a significant role in establishing urban hydrologic response (Meierdiercks et al., 2010b). Land clearing and paving and grading of surfaces for urban development contribute to major changes in catchment water quantity (GHD, 2017). Land clearing results in reduced vegetation, decreasing the available interception storage and protective covering of natural vegetation (Leopold, 1968). This, along with paving of surfaces, leads to reduced potential for infiltration, reduced surface roughness, and more surface runoff (Davis and McCuen, 2005). Grading of surfaces reduces the available depression storage (Douglas, 2015). This reduction in storage and roughness increases the volume and decreases the travel time of runoff, resulting in increased peak runoff rates (Sauer et al., 1983). In heavy precipitation events, overbank flows may occur. Over time, large runoff volumes will also lead to channel erosion, flooding issues, and possible infrastructure damage (Douglas, 2015). 


\subsubsection{Stormwater Control Measures}

In the attempt to compensate for lost natural storage and minimize flood risk, many municipalities require the installation of stormwater control measures (SCMs) (Environment Canada, 2018). While SCMs are unable to restore pre-development flow regimes, they can extend lag times relative to existing development conditions (James and Dymond, 2011). Implementation of SCMs has been found to reduce mean annual runoff by $35 \%$ or more at the watershed scale (Meierdiercks et al., 2010a).

Since 2003, the province of Ontario has promoted a 'treatment train' approach to stormwater control. This prioritizes prevention (e.g. by effective street cleaning, reducing street widths and driveway lengths), then lot-level controls (e.g. rainwater harvesting, soakaway pits), then conveyance controls (e.g. pervious pipe systems, grass swales), and lastly, end-of-pipe controls (e.g. stormwater wetlands, wet ponds) (Ontario Ministry of the Environment, 2003; Bradford and Gharabaghi, 2004). Other examples of SCMs include infiltration pits, roadside swales, green roofs, and permeable pavements (Casey et al., 2013). Among the most common structures for end-of-pipe stormwater management are stormwater detention basins, also known as stormwater management ponds.

\subsubsection{Stormwater Management Ponds}

SWMPs allow runoff collected in stormwater sewers to pool temporarily (LSRCA, 2011). The pond's outlet releases water from the pond to a nearby stream system at a controlled rate, thus controlling the flow of water and reducing dramatic changes in streamflow volume during rain events (TRCA, 2012). These ponds are poor mimics of natural systems (Rooney et 
al., 2015), but are effective in reducing peak discharges at the lot level (LSRCA, 2011). Results of stormwater control modelling in Baltimore County's Dead Run watershed suggest that the presence of SWMPs impacts peak discharges more significantly than land use type or percent impervious area (Meierdiercks et al., 2010b).

Most municipalities use SWMPs to slow the movement of stormwater runoff, and the ponds can cover up to $4 \%$ of the municipality's area (Douglas, 2015). The ponds are often linked to green corridors with ecological value that double as public recreational areas (Brilly, 2007; Hassall and Anderson, 2015). These corridors are intended to preserve areas with significant biodiversity and wildlife habitat while connecting the public to trails and greenways (Moore and Hunt, 2012; Houck, 2015).

\subsection{Impacts of Urbanization on Water Quality}

Increasing urbanization has adverse impacts on the water quality of terrestrial groundwater and aquatic systems (Walsh et al., 2005; Douglas, 2011). Pollution from both point and non-point sources can be transported to streams along a variety of pathways, resulting in elevated nutrient, sediment, and pathogen loads (Ehrenfeld et al., 2015). In Ontario's urbanizing Lake Simcoe watershed, the primary pollutants are phosphorus, nitrogen, and $\mathrm{Cl}^{-}$; phosphorus from urban runoff and septic systems, nitrogen from agriculture, and $\mathrm{Cl}^{-}$from surface runoff (O’Connor et al., 2012). 


\subsubsection{Pollution of Urban Waterways}

For most of North America in the $20^{\text {th }}$ century, point source discharges represented the majority of pollutant inputs—mostly organic wastes, toxic compounds, and nutrients-to freshwater systems (Davis and McCuen, 2005). Controlling regulations were put into practice and largely addressed the problem in the 1970s. However, non-point sources of pollution such as stormwater runoff were not regulated in the same way (Davis and McCuen, 2005).

Today, most pollutant inputs to aquatic systems are from non-point sources. Pollutants are derived from multiple sources such as industrial effluent, nutrient-rich runoff from upstream agricultural areas, and urban development (Walsh et al., 2012). Oils and grease, road salt, heavy metals, pesticides and fertilizers, and pathogenic microorganisms are common contaminants in urban and urbanizing areas (Gray and Becker, 2002; Davis and McCuen, 2005; Soller et al., 2005; Arnone and Perdek Walling, 2007; Egemose et al., 2015). Surface runoff transports these pollutants rapidly to receiving streams (Bazinet et al., 2010; Cooper et al., 2014). Because of this, the degradation of stream water quality is highly correlated to increasing watershed population and impervious surface area (Walsh et al., 2005; Oswald et al., 2019).

\subsubsection{Water Quality in Stormwater Management Ponds}

SWMPs are thought to improve stream water quality largely because the ponds offer opportunities for runoff to pool. As the water is detained, suspended solids and associated pollutants are allowed to settle out (Gallagher et al., 2011; Schwartz et al., 2017).

Biogeochemical and physicochemical processes can remove pollutants. For example, SWMPs allow interaction of denitrifiers in sediment with nitrate-laden water, increasing potential for 
denitrification (Bettez and Groffman, 2012). Additionally, buffer areas around the ponds are usually landscaped with natural vegetation for nutrient uptake and filtering of sediment (Moore and Hunt, 2012). These mitigating processes work well at low flow rates but are less effective during high flow events when retention time is short and currents may scour the bottom of the pond, carrying out previously captured sediments and pollutants (Davis and McCuen, 2005).

Therefore, there is some concern around whether SWMPs are exacerbating downstream impacts of polluted stormwater runoff. For example, in Delaware, eight SWMPs failed to prevent the nearly complete downstream loss of sensitive benthic macroinvertebrate taxa once the catchment exceeded 20\% impervious area (Maxted and Shaver, 1997). SWMP water and sediment frequently exceed Canadian Water Quality Guidelines (CWQGs) for contaminants such as chromium, lead, zinc, and PAHs, especially as they age (Bishop et al., 2000; LSRCA, 2011). There are also pollutants, such as $\mathrm{Cl}^{-}$, that do not settle out once the water is pooled; it is unclear whether and how SWMPs treat such pollutants (Ehrenfeld et al., 2015).

\section{4 $\mathrm{Cl}^{-}$in Urban Environments}

$\mathrm{Cl}^{-}$is abundant in the environment (Kelly et al., 2008; Tyree et al., 2016). Sources of $\mathrm{Cl}^{-}$ to ecosystems can be naturally occurring, such as natural salt deposits, rock weathering, and dry deposition (Oswald et al., 2019). Anthropogenic sources of $\mathrm{Cl}^{-}$include water softeners, wastewater treatment effluent, agriculture, and road deicing salt (Kelly et al., 2008). 
In rural watersheds, agricultural runoff accounts for a significant proportion of environmental $\mathrm{Cl}^{-}$, due to the use of $\mathrm{KCl}$ fertilizers (Corsi et al., 2015). However, in urban areas, road salt $\left(97 \%\right.$ sodium chloride $(\mathrm{NaCl})$ in Canada) is the dominant contributor of $\mathrm{Cl}^{-}$and increased salinity to aquatic systems (Kaushal et al., 2005; Chapra et al., 2009; Winter et al., 2011; Oswald et al., 2019). $\mathrm{NaCl}$ dissolves readily in meltwater and contributes to elevated $\mathrm{Cl}^{-}$ concentrations in ground and surface waters year-round (Judd, 1970; Todd and Kaltenecker, 2012).

Small ponds and streams draining large urban and urbanizing areas are the most sensitive to road salt inputs (Mayer et al., 1999). In urbanizing watersheds in southern Ontario, stream $\mathrm{Cl}^{-}$ loads are highest in the spring (54\% of annual total); the summer and fall months account for approximately $12 \%$ of the annual load (O'Connor et al., 2012).

\subsubsection{Road Salt Usage in North America}

Road salt application on paved surfaces in a typical North American city can average 2.2 $\mathrm{kg} \mathrm{m}^{-2}$ per year (Meriano et al., 2009). This number increases with increasing urbanization, as does stream $\mathrm{Cl}^{-}$concentrations (Corsi et al., 2015). It has been found that this increase is not linear. In a ten-year study conducted by Wallace and Biastoch (2016), mean $\mathrm{Cl}^{-}$concentration increased by $48 \%$, while road density only increased by $6 \%$. This may be because, while government-level management of road salt application has generally improved, private applicators (e.g. homeowners, businesses, building operators) are not subject to regulation (Labashosky, 2015; Ontario Ministry of the Environment, Conservation, and Parks, 2017; Environment Canada, 2018). 
Canada's current Code of Practice (Environment Canada, 2018) for the management of road salts came into effect in 1999 after a five-year assessment of $\mathrm{Cl}^{-}$salts and brines used in road-deicing was carried out under the Canadian Environmental Protection Act. The Code recommends the development of Salt Management Plans and implementation of best management practices as outlined in the Syntheses of Best Practices developed by the Transportation Association of Canada. The Plans are meant to be focused on safety, efficiency and cost-effectiveness and should include details on spreading, Salt Vulnerable Areas, salt storage, training, and monitoring (TAC, 2013). The best management practices are focused on reducing negative effects of road salts by placing an emphasis on correct quantity, location, and timing of road salt application (TAC, 2013; Environment Canada, 2018).

The City of Toronto had a $26 \%$ reduction in the rate of road salt applied after implementing mitigations from the Code of Practice, and it was thought that this might provide ecological benefit to fourteen to twenty-eight species of fish, invertebrates, and plants (Kilgour et al., 2014). However, these benefits are likely undermined in urbanizing watersheds where road networks, and thus areas of road salt application, continue to expand (O'Connor et al., 2012).

\subsection{2 $\mathrm{Cl}^{-}$Transport Through Urban Watersheds}

The $\mathrm{Cl}^{-}$ion does not settle, is not removed biologically, is highly soluble and not subject to any considerable degree of degradation. These properties make $\mathrm{Cl}^{-}$an ideal tracer for watershed urbanization over time (Thunqvist, 2004; Chapra et al., 2009; Kaushal et al., 2014).

Many natural and manmade streams and ponds receive runoff directly via overland flow and indirectly via subsurface flow from urban streets and highways (Oswald et al., 2019). When 
deicing salt is transported into waterways, some is transported via overland flow, while some accumulates in the shallow subsurface (Meriano et al., 2009). In these cases, salt concentrations in both nearby groundwater and surface water increase rapidly (Löfgren, 2001). Small amounts of $\mathrm{Cl}^{-}$may be retained by plants, but more is retained in soils and groundwater (Kelly et al., 2008). Up to $77 \%$ of $\mathrm{Cl}^{-}$from road salt applied in a given deicing season may be retained in the watershed (Novotny and Stefan, 2010; Perera et al., 2010).

These $\mathrm{Cl}^{-}$transport pathways are illustrated through watershed-scale mass balance studies, which often use road area along with provincial and municipal road salt application data (Chapra et al., 2009; Oswald et al., 2019) and estimates for private applications (Meriano et al., 2009) to deduce inputs, and conductivity monitoring to deduce outputs (Kelly et al., 2008;

Chapra et al., 2009; Meriano et al., 2009).

Baseline $\mathrm{Cl}^{-}$concentrations increase over time as continued salt input overwhelms the system's ability to recover to background concentrations before the next deicing season begins (Corsi et al., 2015). In the warm seasons, $\mathrm{Cl}^{-}$can still be released into stream networks via baseflow. Such multi-season impacts suggest that extended-duration exposure to $\mathrm{Cl}^{-}$in urban streams would be possible, placing some aquatic organisms at risk outside of the winter period during dry weather flow conditions (Perera et al., 2010).

\subsubsection{1 $\mathrm{Cl}^{-}$Transport Through Stormwater Management Ponds}

SWMPs are an accepted best management practice for attenuating peak flows but have been criticized as inefficient with regards to mitigating negative water quality impacts (Gold $e t$ al., 2017). Without frequent maintenance such as sediment removal, SWMPs may promote long- 
term storage and gradual release of $\mathrm{Cl}^{-}$and may play a role in mobilization of other roadwayderived contaminants (Casey et al., 2013).

Casey et al. (2013) assessed salt accumulation in surface waters of ponds, groundwater beneath ponds, and ground and surface water of adjacent floodplains. They noted that road salt application had year-round impacts on $\mathrm{Cl}^{-}$concentrations in surface water of ponds and groundwater beneath ponds, and that specific conductance of groundwater in floodplains draining SWMPs was consistently elevated. They concluded that subsurface leakage from SWMPs is a source of groundwater salinity, and that $\mathrm{Cl}^{-}$-enriched groundwater can be discharged to surface water year-round.

Snodgrass et al. (2017) carried out a similar study in three different watersheds with differing degrees of stormwater control, including SWMPs. They found that $\mathrm{Cl}^{-}$concentrations in pond outflows were at their maximum in February, declining by June, and at their minimum in November. This pattern occurred in all watersheds, but watersheds with SWMPs experienced lesser declines. These watersheds also experienced higher baseflow conductivity and larger conductivity spikes following storm events. In agreement with Casey et al. (2013), they concluded that SWMPs were not preventing the release of $\mathrm{Cl}^{-}$in high concentrations to streams and were releasing highly contaminated flows year-round.

Incoming stormwater, with elevated $\mathrm{Cl}^{-}$concentrations, can enter a pond as a buoyant jet (tending to rise), interflow (tending to mix), or a sinking jet (tending to sink), depending on incoming flow rate and existing in-pond stratification (Marsalek, 2003). Marsalek (2003) observed densimetric stratification in an urban SWMP, with the $\mathrm{Cl}^{-}$concentration at the surface being $20 \%$ to $50 \%$ that of the concentration at the bottom. Strong stratification can inhibit vertical mixing and thus, aeration of bottom layers (Duan et al., 2016). The low levels of oxygen 
at the bottom of the pond, combined with high concentrations of $\mathrm{Cl}^{-}$, results in toxic environments for certain biota, and may stimulate contaminant release from the sediment (Schwartz et al., 2017). Depending on the depth at which pond water is released, the impact on downstream $\mathrm{Cl}^{-}$concentrations may change. For example, ponds that are designed to release stormwater through bottom outlets throughout the winter may prevent strong stratification (Marsalek, 2003).

The role that SWMPs play in the timing and magnitude of $\mathrm{Cl}^{-}$transport through urban and urbanizing watersheds is not well understood. While the effects of road salting practices on soil, surface water, groundwater, and aquatic communities were recognized by the 1970s (Judd, 1970; Bubeck et al., 1971; Huling and Hollocher, 1972; Kunkle, 1972; Crowther and Hynes, 1977), $\mathrm{Cl}^{-}$in stormwater ponds had not been studied until the early 2000s. Prominent research to date detailing $\mathrm{Cl}^{-}$in stormwater management ponds and their environs includes the study by Casey et al. (2013) describing the year-round impacts of road salt application, and the study by Snodgrass et al. (2017) describing pond $\mathrm{Cl}^{-}$concentrations in different watersheds. The former did not carry out a mass balance, and the latter did not consider differing temporal scales.

\subsubsection{Long-Term $\mathrm{Cl}^{-}$Concentration Trends in Freshwater Systems}

Elevated $\mathrm{Cl}^{-}$first became a concern in Ontario in the mid-1960s, when Alfred Beeton (1965) reported that $\mathrm{Cl}^{-}$concentrations had been rising in the Great Lakes starting as early as the late 19th century. O'Connor and Mueller (1970) developed $\mathrm{Cl}^{-}$models that corroborated Beeton's findings and suggested that the increases were primarily due to industrial discharges 
and runoff of deicing salts. Industrial controls around the Great Lakes introduced in the 1960s started to slow the long-term build-up of $\mathrm{Cl}^{-}$(Chapra, 2009).

Kelly et al. (2008) conducted a long-term study of $\mathrm{Cl}^{-}$concentrations and road salt use in rural New York from 1986 to 2005; while road salt use did not increase, stream $\mathrm{Cl}^{-}$

concentrations increased by an average of $1.5 \mathrm{mg} \mathrm{L}^{-1}$ per year. This lag effect likely arose from subsurface build up from long-term road salt application (Kelly et al., 2008; Casey et al., 2013).

Winter et al. (2011) examined $\mathrm{Cl}^{-}$concentrations over time in and around Ontario's Lake Simcoe and found that, between 1993 and 2007, lake $\mathrm{Cl}^{-}$concentrations increased by up to 10 $m g \mathrm{~L}^{-1}$ per year. $\mathrm{Cl}^{-}$fluxes were positively correlated with the proportion of urban land and number of roads drained (Winter et al., 2011). Slightly south of Lake Simcoe, in Toronto, Wallace and Biastoch (2016) found that in 2002,33\% of winter stream samples exceeded CWQG chronic $\mathrm{Cl}^{-}$limits of $120 \mathrm{mg} \mathrm{L}^{-1}$; in 2012, 58\% of samples exceeded CWQG chronic $\mathrm{Cl}^{-}$ limits (CCME, 2011) . Clearly, $\mathrm{Cl}^{-}$is an increasing threat to freshwater systems.

\subsubsection{Effects of Elevated $\mathrm{Cl}^{-}$on Freshwater Systems}

The application of deicing salt causes secondary effects for urban freshwater systems including but not limited to increased mobility of metals (Norrström and Jacks, 1998) and reduced acid neutralizing capacity in surface water by ion exchange (White, 2000; Löfgren, 2001). Other impacts can be physical, chemical, or biological. Density gradients and circulation of receiving water bodies may be altered (Bubeck et al., 1971; Diment et al., 1973). Dissolved oxygen may be depleted, as increased salinity reduces the ability to dissolve oxygen (Davis, 1975; LSRCA, 2011). Increasing $\mathrm{Cl}^{-}$and other contaminants in urban runoff are strong drivers of 
species loss; diversity is reduced and smaller populations and shifts to pollutant-tolerant species are observed (Maltby et al., 1995; Wallace and Biastoch, 2016; Walsh and Webb, 2016).

Overall, road salt and other urban contaminants contribute to what has been coined as the Urban Stream Syndrome (USS). USS describes a trend towards elevated contaminant profiles and flashier hydrographs in streams of urban catchments (Walsh et al., 2005; Booth et al., 2016). Additional 'symptoms' of USS include altered channel morphology and distorted biotic assemblages, favouring pollutant-tolerant invertebrates, fish, and plants (Paul and Meyer, 2001).

\subsubsection{Current Methods of $\mathrm{Cl}^{-}$Mitigation}

Four primary design features for reduction of salt use were identified by GHD, retained by the LSRCA to prepare guidelines on salt reduction (GHD, 2017). First was the reduction of paved surfaces by adding vegetated features such as landscaped islands. It is also critical to promote effective grading and stormwater collection to minimize freezing of wet surfaces and prevent meltwater from ponding and later refreezing, requiring further salt treatment. Snow storage piles should be placed strategically to reduce the likelihood of meltwater draining across high traffic areas and refreezing. Lastly, layout of pedestrian walkways should be carefully considered to reduce salting of unused walkways. Beyond these design features, Ontario conservation authorities are increasingly promoting public education initiatives to limit pollutants from entering SCMs (LSRCA, 2011; TRCA, 2012). 


\section{Quantifying Chloride Retention in Urban Stormwater Management Ponds Using a Mass Balance Approach}

\subsection{Introduction}

In urban areas that experience cold and icy winters, chloride $\left(\mathrm{Cl}^{-}\right)$-based road salts are applied to paved surfaces to maintain safe driving conditions (Novotny and Stefan, 2010; Perera et al., 2010; Oswald et al., 2019). Road salts dissolve readily in water and contribute to elevated $\mathrm{Cl}^{-}$concentrations in ground and surface waters year-round (Judd, 1970; Howard and Haynes, 1993; Daley et al., 2009; Kincaid and Findlay, 2009; Todd and Kaltenecker, 2012; Robinson et al., 2017; Kelly et al., 2019). While there are other anthropogenic sources of $\mathrm{Cl}^{-}$, including wastewater treatment effluent (Vengosh and Pankratov, 1998; Panno et al., 2006), water softeners (Kaushal, 2016; Lax et al., 2017), and agricultural fertilizers (Sherwood, 1989; Hill and Sadowski, 2016), road salt is the dominant contributor of $\mathrm{Cl}^{-}$and increased salinity to urban aquatic systems (Sherwood, 1989; Mayer et al., 1999; Kaushal et al., 2005; Chapra et al., 2009; Winter et al., 2011).

Even with improved management practices (Environment Canada, 2018), mean annual stream $\mathrm{Cl}^{-}$concentrations have continued to increase with increasing urbanization (Kelly et al., 2008; Corsi et al., 2015; Oswald et al., 2019; Kelly et al., 2019). Increasing lake $\mathrm{Cl}^{-}$ concentrations have also been observed (Beeton, 1965; Chapra et al., 2009; Dugan et al., 2017) in lakes with greater than $1 \%$ impervious surface area within a 500m buffer (Dugan et al., 2017). Typical background $\mathrm{Cl}^{-}$concentrations in natural surface waters are around $10 \mathrm{mg} \mathrm{L}^{-1}$, and $\mathrm{Cl}^{-}$is relatively benign at low concentrations (Fellenberg, 2000). However, $\mathrm{Cl}^{-}$has negative 
toxicological impacts on aquatic biota as chronic concentrations exceed $120 \mathrm{mg} \mathrm{L}^{-1}$ and/or acute concentrations exceed $640 \mathrm{mg} \mathrm{L}^{-1}$ (Fellenberg, 2000; Corsi et al., 2010; CCME, 2011; Walsh et al., 2012; Brown and Yan, 2015; Wallace and Biastoch, 2016). These exposure concentrations do not necessarily apply to all species; for example, some species of endangered and special concern freshwater mussels may not be protected at a long-term $\mathrm{Cl}^{-}$concentration of $120 \mathrm{mg} \mathrm{L}^{-1}$ (CCME, 2011). Elevated $\mathrm{Cl}^{-}$concentrations in surface waters can alter the composition of aquatic communities and cause species richness and abundance to decline (Karraker et al., 2008; Hintz et al., 2017; Jones et al., 2017). Freshwater species at all trophic levels, as well as nutrient and energy flows at the ecosystem scale, may be negatively impacted (Van Meter and Swan, 2014; Hintz and Relyea, 2019). Elevated $\mathrm{Cl}^{-}$concentrations can also result in increased transport and bioavailability of heavy metals (Schuler and Relyea, 2018) and increased lake stratification, resulting in anoxia and nutrient resuspension (Sibert et al., 2015; Dupuis et al., 2019). These changes drive species loss, reduced diversity and population densities, and population shifts to pollutant-tolerant species (Maltby et al., 1995; Searle et al., 2016; Wallace and Biastoch, 2016; Walsh and Webb, 2016).

The $\mathrm{Cl}^{-}$ion does not settle, is not removed biologically, is highly soluble and not subject to any considerable degree of degradation (Cerendulo, 1988; Environment Canada, 2001; Thunqvist, 2004; Chapra, 2009). Precipitation and snowmelt events wash $\mathrm{Cl}^{-}$off of paved surfaces and it is then transported via subsurface flow, piped flow, or overland flow to receiving waters (Oswald et al., 2019). Given its conservative nature, $\mathrm{Cl}^{-}$can accumulate over time in groundwater (Williams et al., 2000; Panno et al., 2006; Howard and Maier, 2007), and be transported into streams, rivers (Löfgren, 2001; Thunqvist, 2004; Kaushal et al., 2005; Kelly et al., 2008; Corsi et al., 2010, 2015), and lakes (Novotny et al., 2008; Chapra et al., 2009; Meriano 
et al., 2009; Likens and Buso, 2010; Müller and Gächter, 2012; Swinton et al., 2015). Previous studies have shown that 28 to $77 \%$ of $\mathrm{Cl}^{-}$from road salt applied in a given deicing season may be retained in the watershed in groundwater and stormwater control measures (SCMs) (Novotny and Stefan, 2010; Perera et al., 2010; Casey et al., 2013; Oswald et al., 2019), creating a legacy effect that can maintain elevated $\mathrm{Cl}^{-}$concentrations into the growing season, even if salt application is reduced (Gutchess et al., 2016; Kelly et al., 2019). The role that SCMs play in retaining $\mathrm{Cl}^{-}$and influencing downstream $\mathrm{Cl}^{-}$dynamics is not well studied.

SCMs were developed for flood protection and to mitigate water quality problems associated with suspended sediment (Fletcher et al., 2013; Environment Canada, 2018; Pennino et al., 2016). A common end-of-pipe SCM is the stormwater management pond (SWMP) (OME, 2003; Bradford and Gharabaghi, 2004). SWMPs are considered a best management practice for attenuating peak flows and allowing suspended sediments to settle out (Meierdiercks et al., 2010b; Newcomer Johnson et al., 2014). However, previous research suggests that SWMPs could promote long-term storage and release of $\mathrm{Cl}^{-}$due to densimetric stratification (Marsalek, 2003) and potential leakage to groundwater (Casey et al., 2013). On the watershed scale, it is expected that SWMPs are not retaining high amounts of $\mathrm{Cl}^{-}$relative to overall watershed loads (Snodgrass et al., 2017); however, in some watersheds, for example the East Holland River watershed in southern Ontario, Canada, over $40 \%$ of the urban watershed area is drained through SWMPs. Given the wide range in area drained through SWMPs in watersheds across this region and the continued use of SWMPs for stormwater management in urbanizing areas, a better understanding of $\mathrm{Cl}^{-}$retention in SWMPs over different time scales is warranted. We addressed this research gap by quantifying $\mathrm{Cl}^{-}$retention for two SWMPs located in the East Holland River watershed in southern Ontario, Canada and examining the influence of pond $\mathrm{Cl}^{-}$export on 
downstream water quality for one of the SWMPs. Our four specific objectives were to: (1) quantify the mass of $\mathrm{Cl}^{-}$entering and leaving the SWMPs; (2) determine annual, seasonal, and event-scale $\mathrm{Cl}^{-}$retention for the SWMPs using a mass balance approach; (3) compare changes in $\mathrm{Cl}^{-}$retention in the ponds estimated in (1) to in-pond surface and bottom $\mathrm{Cl}^{-}$concentrations; and (4) quantify the response of a receiving stream to $\mathrm{Cl}^{-}$exported from one of the SWMPs. The results of this study will be used to parameterize the role of SWMPs in watershed-scale $\mathrm{Cl}^{-}$ transport models and geospatial models of Salt Vulnerable Areas (SVAs).

\subsection{Methodology}

\subsubsection{Study Watershed}

The $247 \mathrm{~km}^{2}$ East Holland River (EHR) watershed (Figure 1) drains into Lake Simcoe, which is located in south-central Ontario, Canada. Land use in EHR is 24\% wetland and forest, $35 \%$ agriculture, and $40 \%$ urban (Oswald et al., 2019). Urban expansion is occurring in the southern part of the watershed while agricultural practices occur in the northern and southeastern parts of the watershed. The average annual precipitation in EHR is $858 \mathrm{~mm}$, of which $14.25 \%$ is snow. Snowfall occurs from November to April. The mean air temperature in $\mathrm{EHR}$ is $7^{\circ} \mathrm{C}(\mathrm{EC}$ Weather Office, 2019). It is on glacial till and mostly composed of glaciolacustrine silt and clay. EHR has very deep bedrock and long flow paths (Oswald et al., 2019). 65\% of the EHR drains through SWMPs. Approximately one-sixth of the Lake Simcoe watershed is predicted to exceed the Canadian Water Quality Guidelines (CWQG) for the protection of aquatic life for chronic exposure to $\mathrm{Cl}^{-}$(LSRCA, 2015). EHR is one of two sub-watersheds in the Lake Simcoe basin to host the greatest number of aquatic taxa impacted by $\mathrm{Cl}^{-}$(LSRCA, 2015). 


\subsubsection{Study Stormwater Management Ponds}

This study examines two SWMPs located in the EHR watershed (Figure 1). The Don Hillock (DH) pond has one inlet, one outlet, one overflow route, a maximum area of $8920 \mathrm{~m}^{2}$ and a maximum depth of $1.7 \mathrm{~m}$. DH was constructed in 2006, drains a business park area (Town of Aurora, 2010), and has a contributing catchment of $133,000 \mathrm{~m}^{2}$, of which $93 \%$ is directly connected impervious area (DCIA). DCIA is defined as "the portion of impervious area with a direct hydraulic connection to the waterbody via continuous paved surfaces, gutters, drain pipes, or other conventional conveyance and detention structures that do not reduce runoff volume" (USEPA, 2011). The Oaktree (OAK) pond has one inlet, one outlet, two overflow routes, a maximum area of $3812 \mathrm{~m}^{2}$ and a maximum depth of $2.2 \mathrm{~m}$. OAK was constructed in 2004, drains a stable residential area (Town of Newmarket, 2014), and has a contributing catchment of 48,000 $\mathrm{m}^{2}$, of which $96 \%$ is DCIA. Both ponds contribute to first order headwater streams; DH contributes to the beginning of the stream and OAK connects along a stream reach. Both ponds fall under the jurisdiction of the Lake Simcoe Region Conservation Authority (LSRCA) and were selected because they were part of a broad-scale pond study examining water and sediment balance, hence water quality and flow monitoring data for these ponds were available from the LSRCA for this study. The ponds are clay-lined with bottom-draw outlets and release water into streams that join the EHR. 


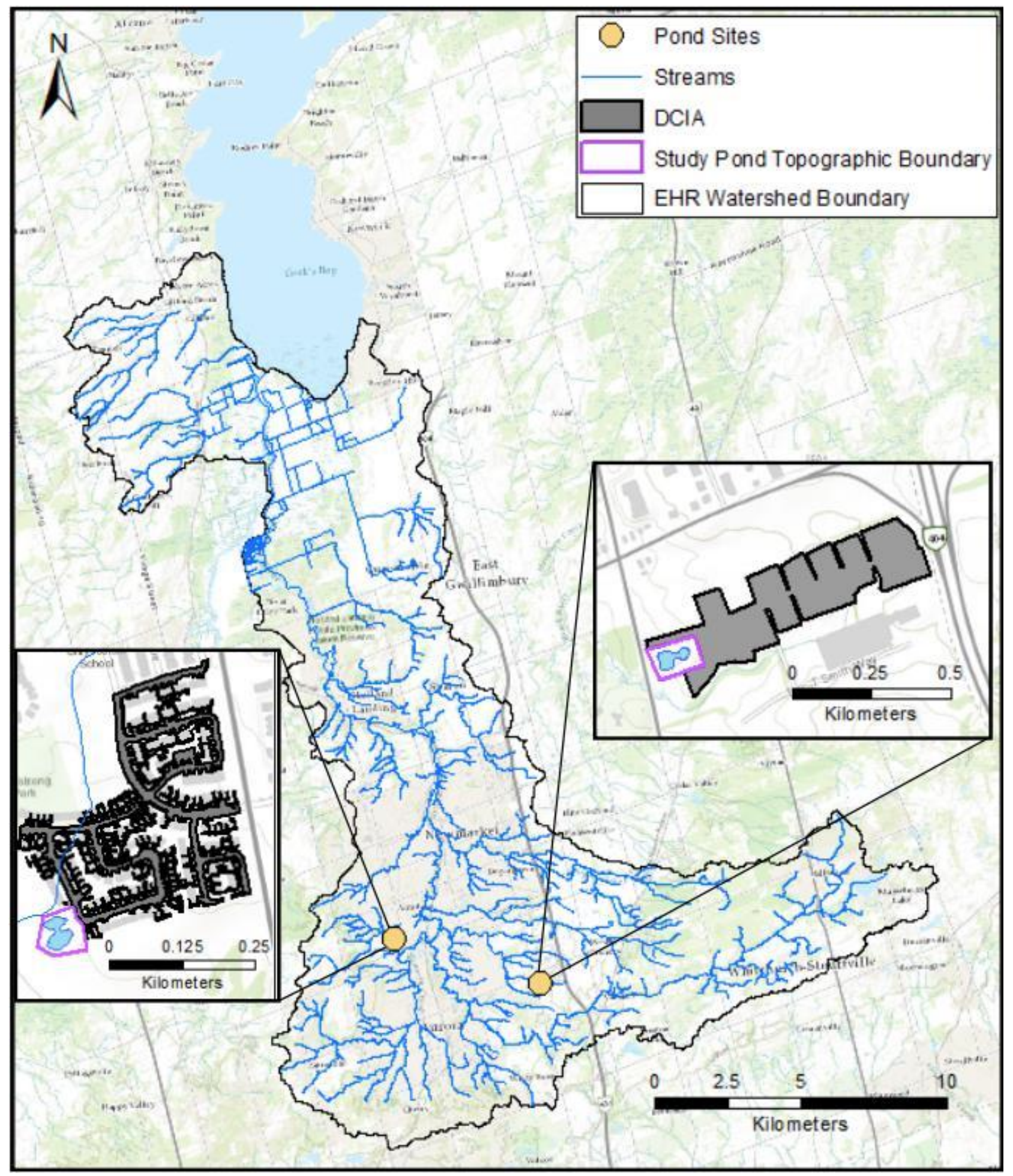

Figure 1. EHR watershed boundary relative to Lake Simcoe. Inset maps are OAK (upper) and DH (lower) and their contributing catchments, indicated by the directly connected impervious area (DCIA) and study pond topographic boundaries. 


\subsubsection{Chloride Concentrations}

Solinst ${ }^{\circledR}$ Leveloggers recording water temperature, level, and conductivity measurements at 15-minute intervals were deployed for 24 months (November 2016 to November 2018) at both ponds' inlets and outlets, and an additional 6 months (up to April 2019) at the OAK inlet and outlet. Levelogger level measurements were corrected for barometric pressure using historical climate data from the Toronto Buttonville A weather station (Environment Canada, 2019). As we were unable to access the inside of the inlet and outlet pipes, the Leveloggers were deployed at the mouths of the pipes. LSRCA also deployed 2 conductivity probes each in the DH forebay and wet cell (June 2016 to May 2018); one was positioned 20cm above the bottom of the pond, and the second $20 \mathrm{~cm}$ below the surface of the pond. Leveloggers recording water temperature, level, and conductivity were also deployed for 8 months (August 2018 to April 2019) upstream and downstream of the confluence of the OAK outlet and the receiving tributary of Tannery Creek to quantify the impact of pond $\mathrm{Cl}^{-}$export on in-stream $\mathrm{Cl}^{-}$concentration. $\mathrm{DH}$ and another pond contribute equally to the beginning of a headwater stream and therefore upstream and downstream impacts of $\mathrm{Cl}^{-}$export from $\mathrm{DH}$ were not measurable.

As most urban stream chemistry shows a linear relation between $\mathrm{Cl}^{-}$concentration and specific conductance, high-frequency monitoring for conductivity is accepted as a proxy method for collecting long-term $\mathrm{Cl}^{-}$data (Sanford et al., 2012; Casey et al., 2013; Hubbart et al., 2017). The actual conductivity measured by the Solinst ${ }^{\circledR}$ Leveloggers used in this study was converted to specific conductance as follows:

$$
S c=\frac{A c}{1+r(T-25)}
$$


where $\mathrm{Sc}$ is the specific conductance in $\mu \mathrm{S} \mathrm{cm}^{-1}$, Ac is the actual conductivity in $\mu \mathrm{S} \mathrm{cm}^{-1}$, T is the water temperature in ${ }^{\circ} \mathrm{C}$ and $\mathrm{r}$ is a temperature correction coefficient (Carlson, 1999).

Monthly grab samples were taken over the course of one year (March 2018 to February 2019) at pond inlets and outlets to calibrate the $\mathrm{Cl}^{-}$concentration-specific conductance relationship (Cooper et al., 2014). Samples were also collected during two rain events (summer and fall 2018) and two melt events (winter 2018 and winter 2019) to better define the relationship at high $\mathrm{Cl}^{-}$concentrations, as rain-on-snow and snowmelt events contain the largest pollutant loading (Batroney et al., 2009). Samples were collected into clean HDPE bottles and filtered through $0.5 \mu \mathrm{m}$ glass fiber filter discs within 3 days of collection. Filtered samples were kept in the dark at $4^{\circ} \mathrm{C}$ until processed via ion chromatography (USEPA, 2016) using the Thermo Scientific ${ }^{\mathrm{TM}}$ Dionex ${ }^{\mathrm{TM}}$ ICS-6000 HPIC ${ }^{\mathrm{TM}}$ system equipped with IonPac AS18 analytical column $\left(\mathrm{Cl}^{-}\right.$detection limit: $\left.0.1 \mathrm{mg} \mathrm{L}^{-1}\right)$. Ion analyses were conducted by the Biogeochemistry Research Group of the Department of Geography and Environmental Management at the University of Waterloo. The $\mathrm{Cl}^{-}$concentration-specific conductance relationships derived were:

$$
\left[\mathrm{Cl}^{-}\right]=0.2851 \cdot S c-20.75
$$

and

$$
\left[\mathrm{Cl}^{-}\right]=0.3769 \cdot S c-202.4
$$

for $\mathrm{DH}\left(\mathrm{r}^{2}=0.95, \mathrm{n}=39\right)$, and

$$
\left[\mathrm{Cl}^{-}\right]=0.2879 \cdot S c-34.70
$$




$$
\left[\mathrm{Cl}^{-}\right]=0.4389 \cdot S c-443.8
$$

for OAK $\left(\mathrm{r}^{2}=0.99, \mathrm{n}=39\right)$, where $\left[\mathrm{Cl}^{-}\right]$is the $\mathrm{Cl}^{-}$concentration in $\mathrm{mg} \mathrm{L}^{-1}$. Equation (2) was used for specific conductances below $1979 \mu \mathrm{S} \mathrm{cm}^{-1}$, and equation (3) for specific conductances above $1979 \mu \mathrm{S} \mathrm{cm}^{-1}$. Equation (4) was used for specific conductances below $2709 \mu \mathrm{S} \mathrm{cm}^{-1}$, and equation (5) for specific conductances above $2709 \mu \mathrm{S} \mathrm{cm}^{-1}$. These breakpoints and associated relationships were determined using the 'segmented' package for regression models with unknown break-points (Muggeo, 2003; Muggeo, 2008) for the R language and environment for statistical computing (R Core Team, 2017).

\subsubsection{Water Balance and $\mathrm{Cl}^{-}$Mass Balance Calculations}

The LSRCA collected in-pipe level and flow data at the inlets and outlets of both ponds from May 2017 to November 2017 using a V-notch weir at the DH outlet and ISCO 2150 area velocity flow modules at OAK and the DH inlet. The LSRCA in-pipe levels were compared to our corresponding mouth-of-pipe Levelogger level measurements for this study to estimate the relationship between LSRCA levels and our monitored levels $\left(0.95<\mathrm{r}^{2}<0.99\right)$. The level-toflow relationship from LSRCA data was then used to determine flow from our monitored levels for the remaining 21 months $\left(0.73<\mathrm{r}^{2}<0.99\right)$. For each 15 -minute interval, the flow $\left(\mathrm{L} \mathrm{s}^{-1}\right)$ was multiplied by the time interval $(900 \mathrm{~s})$ and corresponding $\mathrm{Cl}^{-}$concentration $\left(\mathrm{mg} \mathrm{L}^{-1}\right)$ to determine the $\mathrm{Cl}^{-}$load. Loads were summed over event, seasonal, and annual time periods. Evaporation from the ponds was estimated using the Thornthwaite formula (Thornthwaite and Holzman, 1939), which derives potential evapotranspiration as a function of air temperature, and Chow's 
adjustment method (Chow, 1965), which corrects for monthly sunshine duration. Precipitation inputs were derived from LSRCA rain gauge data at the Newmarket Office location $\left(44^{\circ} 03^{\prime} 50.3^{\prime \prime} \mathrm{N} 79^{\circ} 27^{\prime} 27.0^{\prime \prime} \mathrm{W}\right)$. This rain gauge is $4.5 \mathrm{~km}$ from OAK and $6.9 \mathrm{~km}$ from DH.

Percent retention was calculated as follows:

$$
\text { Retention }=\frac{\text { Input-Output }}{\text { Input }} \times 100 \%
$$

For the water balance, the output includes outflows and evaporation. Precipitation falling directly onto the ponds' topographic catchments was also considered as an input in the water balance.

For seasonal analyses, the study period was divided into winter (November - April) and summer (May - October) seasons based on historical snowfall data. Years are therefore defined in this study as November - October. The pond outflow hydrographs were classified into event and non-event periods using the USGS HYSEP minimum flow routine (Sloto and Crouse, 1996) executed in $\mathrm{R}$.

\subsubsection{Statistical Analyses}

All statistical analyses were completed using the R language and environment for statistical computing (R Core Team, 2017).

\subsection{Results and Discussion}

\subsubsection{Annual and Seasonal Variability in SWMPs' Water Balances}


OAK retained over $25 \%$ of the water received in both years, while DH released more water than it received in 2017 and retained 50\% in 2018. This raises the possibility that there are other significant inflows and outflows that were not accounted for in this study. Potential inflows that were not accounted for include (i) a second stormwater pipe that did not appear in the DH pond design diagram draining a small parking lot area; and (ii) groundwater flows into the ponds. Potential outflows that were not accounted for include (i) loss under the outlet weir at DH; and (ii) underrepresented outlet flows during high flow events over the area-velocity flow module at OAK. It is also possible that inflow and outflows during winter seasons were under-reported due to freezing of the Leveloggers. Area-velocity sensors also work best at moderate flow and poorly at low and very high flows, so there may be some measurement error associated with our flow estimates.

To verify the accuracy of pond inflows, the DCIA for each pond was multiplied by precipitation amounts over the study period. Inflows at OAK were similar to what precipitation data and DCIA would suggest at approximately $99 \%$ of the expected volume for both winter seasons and approximately $84 \%$ of the expected volume for the summer seasons. Again, the difference may be due to the distance of the precipitation gauge used from the pond $(4.6 \mathrm{~km})$. Inflows at $\mathrm{DH}$ were also similar to what precipitation amounts multiplied by DCIA would suggest $(93 \%$ of expected volume for the winter seasons and $95 \%$ of the expected volume in S18), except during summer 2017 when inflow exceeded the expected volume by $50 \%$. This is likely due to measurement error; there was one very large event in summer 2017 in which DH and the storm system upstream of DH were filled but flow was recorded as very low over the area-velocity sensor. It is likely that there were other similar errors at low or very high flows throughout the summer. 
As the ponds are closed systems and in-pond monitoring indicates that water levels were comparable at the start and end of study years, the water balance was forced to close for the $\mathrm{Cl}^{-}$ balance calculations. Having verified the pond inflows, only outflows were adjusted. As ponds are designed to control the outflow of water, the flows tend to be lower and thus not as accurately captured by the area-velocity sensors. For example, if the pond water balance indicated that water was retained (storage $>0$ ), it was assumed that the equivalent volume of water, with the average $\mathrm{Cl}^{-}$concentration for the season, was released in addition to the recorded $\mathrm{Cl}^{-}$output (Figure 2c, W18 and S18, and Figure 2d). If the pond water balance indicated that water was released (storage $<0$ ), it was assumed that the equivalent volume of water, with the average $\mathrm{Cl}^{-}$concentration for the season, was reduced from the recorded $\mathrm{Cl}^{-}$output (Figure 2c, W17 and S17).

With this adjustment, the volume of water and mass of $\mathrm{Cl}^{-}$received by $\mathrm{DH}$ are much higher than those received by OAK (Tables 2 and 3), which was expected as DH has a larger contributing catchment and larger DCIA. However, DH has 2.65 times more DCIA than OAK yet received over 6 times as much water and over 18 times as much $\mathrm{Cl}^{-}$over the study period. This suggests that land use and land management practices (e.g. irrigation) must be considered along with \% impervious area when modelling $\mathrm{Cl}^{-}$loading across a watershed. For example, there are more parking lots and commercial properties in DH's catchment than in OAK's, where most of the DCIA is composed of residential streets. The Towns of Newmarket and Aurora have road salt application rates of $100 \mathrm{~kg} \mathrm{lane}^{-1} \mathrm{~km}^{-1}$ (unpublished data), which amounts to $33 \mathrm{~g} \mathrm{~m}^{2}$ when an average lane width of $3 \mathrm{~m}$ is assumed. Comparatively, LSRCA monitoring indicates that parking lot application rates are typically $90-100 \mathrm{~g} \mathrm{~m}^{2}$. 

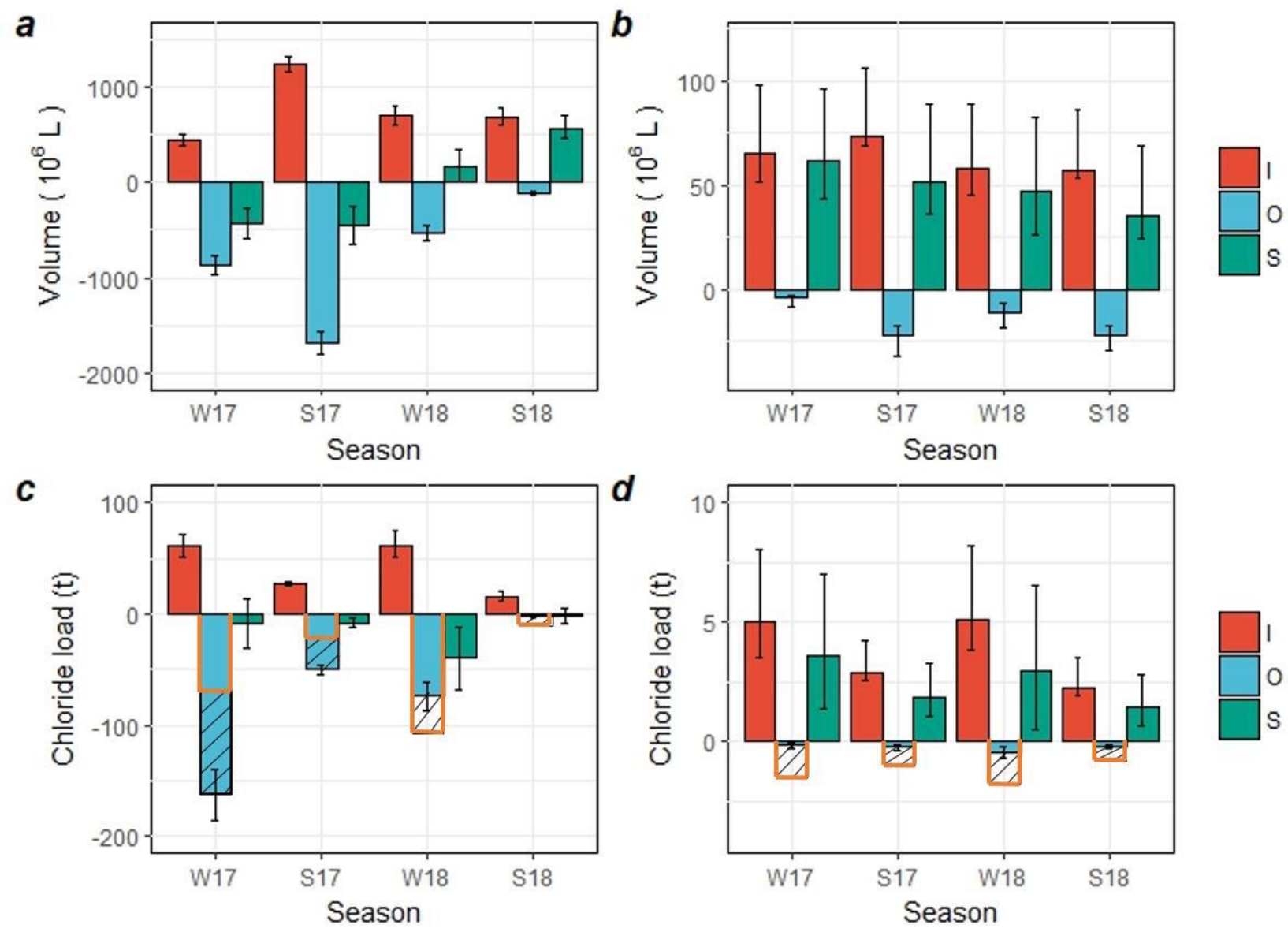

Figure 2. Water and $\mathrm{Cl}^{-}$balances for $\mathrm{DH}((\mathrm{a})$ and (c)) and $\mathrm{OAK}((\mathrm{b})$ and (d)) for each season of the study period $(\mathrm{W}=$ winter, November - April; $\mathrm{S}=$ summer, May - October). For water balances ((a) and (b)), inputs are inflows and precipitation; outputs are outflows and evaporation. $\mathrm{I}=$ input, $\mathrm{O}=$ output, $\mathrm{S}=$ storage (retention). Hatched lines indicate the adjustment applied to the outflow; the bolded outline indicates the outflow used to determine $\mathrm{Cl}^{-}$storage. Note that (i) negative retention indicates release, and (ii) $y$-axes differ between ponds.

\subsubsection{Annual and Seasonal Variability in SWMPs' Cl- Mass Balances}

The $\mathrm{Cl}^{-}$retention differed between the two ponds. DH consistently released $\mathrm{Cl}^{-}$across seasonal and annual scales, whereas OAK consistently retained $\mathrm{Cl}^{-}$(Figure 2). In $\mathrm{OAK}, \mathrm{Cl}^{-}$ retention was greater than $50 \%$ on both annual and seasonal scales throughout the study (Figure 2).

For both ponds, we see that there are still $\mathrm{Cl}^{-}$inputs in the summer seasons. This may be because the $\mathrm{Cl}^{-}$stored in soils over the winter deicing period is being flushed out by infiltrating 
rainwater in the spring and early summer (Higashino et al., 2017). There are $\mathrm{Cl}^{-}$outputs in the summer seasons as well, indicating that the ponds are releasing $\mathrm{Cl}^{-}$-laden water throughout the year. This supports findings from Kelly et al. (2008) that deicing salts contribute to long-term increases in streamwater salt concentrations.

Both ponds had similar patterns of $\mathrm{Cl}^{-}$inputs, with slightly more $\mathrm{Cl}^{-}$received in $\mathrm{W} 18$ than W17, and less $\mathrm{Cl}^{-}$received in S18 than $\mathrm{S} 17$. The deicing season was colder and started earlier in late 2017, likely leading to more road salt application in W18 (November 2017 - April 2018) than in W17 (November 2016 - April 2017). While the total rainfall was similar for S17 and S18, S17 featured larger events; this may have contributed to greater flushing of $\mathrm{Cl}^{-}$stored in soils in $\mathrm{S} 17$ and thus greater $\mathrm{Cl}^{-}$inputs to the ponds in $\mathrm{S} 17$ than in $\mathrm{S} 18$.

\subsubsection{In-Pond $\mathrm{Cl}^{-}$Monitoring}

Water enters the forebay of both SWMPs via stormwater pipes. The forebay is separated from the wet cell (also known as the aft bay) by a berm, so water primarily enters the wet cell from the surface of the forebay. Due to densimetric stratification, water at the pond's surface has lower $\mathrm{Cl}^{-}$concentrations than at depth, so $\mathrm{Cl}^{-}$concentrations in the wet cells are lower throughout the winter and early spring than in the forebay (Figure 3). However, large rainfall events can mobilize $\mathrm{Cl}^{-}$from the forebay into the wet cell, thereby decreasing the forebay $\mathrm{Cl}^{-}$concentrations and increasing the wet cell $\mathrm{Cl}^{-}$concentrations.

Predictably, $\mathrm{Cl}^{-}$concentrations at both the surface and at depth in the forebay and wet cell are relatively lower through the summer, then rise in the winter (Figure 3). In the forebay, winter $\mathrm{Cl}^{-}$concentrations at depth exceed that of saltwater $\left(19,250 \mathrm{mg} \mathrm{L}^{-1}\right)$ at times. Fluctuations in concentrations are of greater magnitude at depth than at the surface. This is because the ponds 
are bottom-drawing; when water is released, $\mathrm{Cl}^{-}$concentrations at depth in the wet cell are the most affected.

The relatively low $\mathrm{Cl}^{-}$concentrations at both the surface and the bottom of the pond in the summer seasons indicates that $\mathrm{Cl}^{-}$should be flushed out of the ponds in late spring (May - June). In 2017, we see that this process occurs over the course of several months (Figure 4), rather than all at once during the spring melt as was observed by Barbier et al. (2018). While the mass balance indicates that this is the case in S17, it is not the case for S18 (not included in Figure 4 as in-pond sensors were removed), when some $\mathrm{Cl}^{-}$was retained. LSRCA monitoring shows that $\mathrm{Cl}^{-}$ persists year-round in some ponds and there is not a full flushing (LSRCA, in press). Possible mechanisms for $\mathrm{Cl}^{-}$retention on an annual basis include uptake by plants and/or release by seepage to groundwater; however, these mechanisms would jointly account for less than $30 \%$ of the annual $\mathrm{Cl}^{-}$retention.
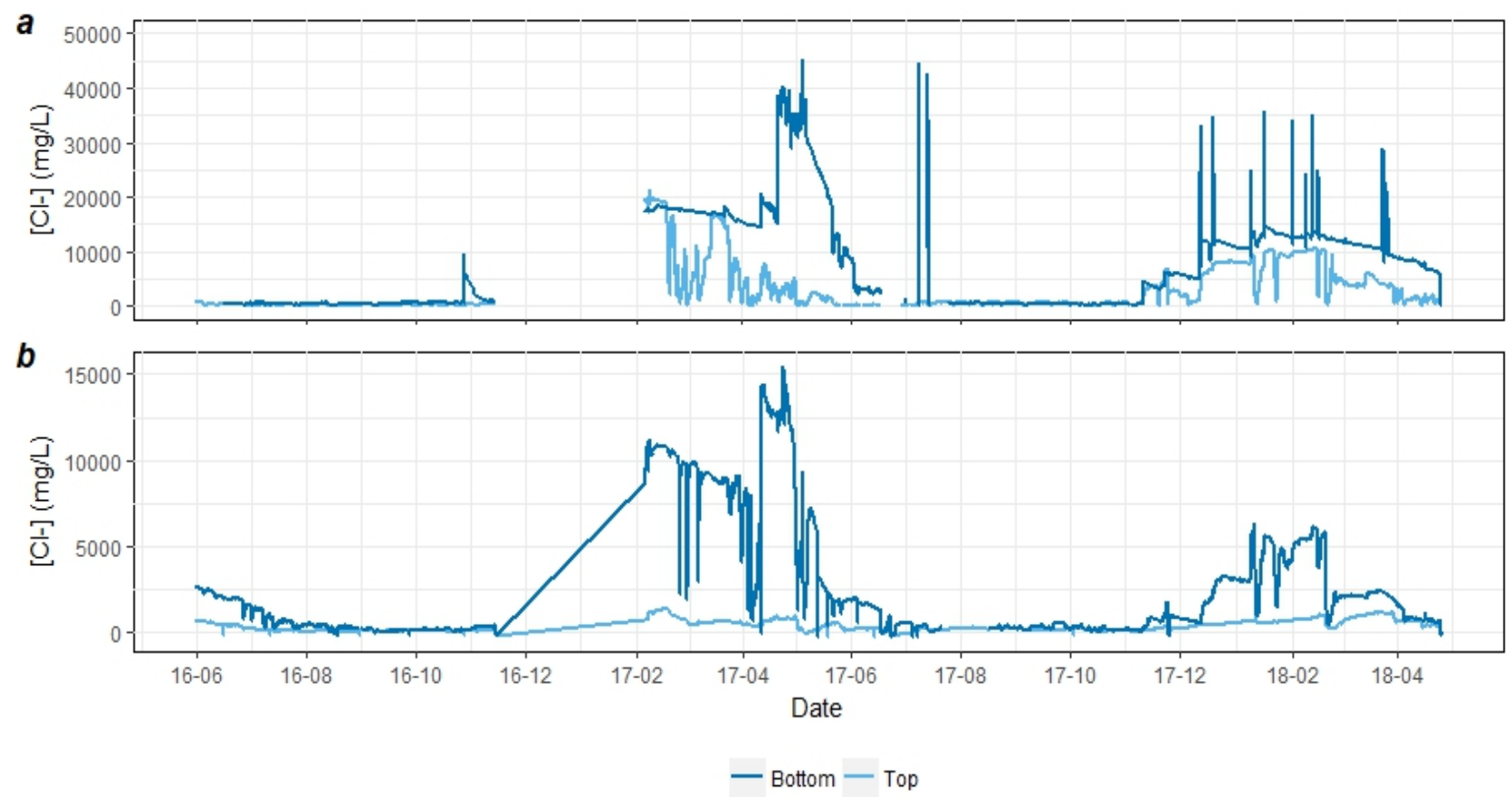

Figure 3. $\mathrm{Cl}^{-}$concentrations in the (a) forebay and (b) wet cell of DH over a 2-year period. Data unavailable in wet cell between Nov '16 and Feb '17. Note the different y-axis ranges. 


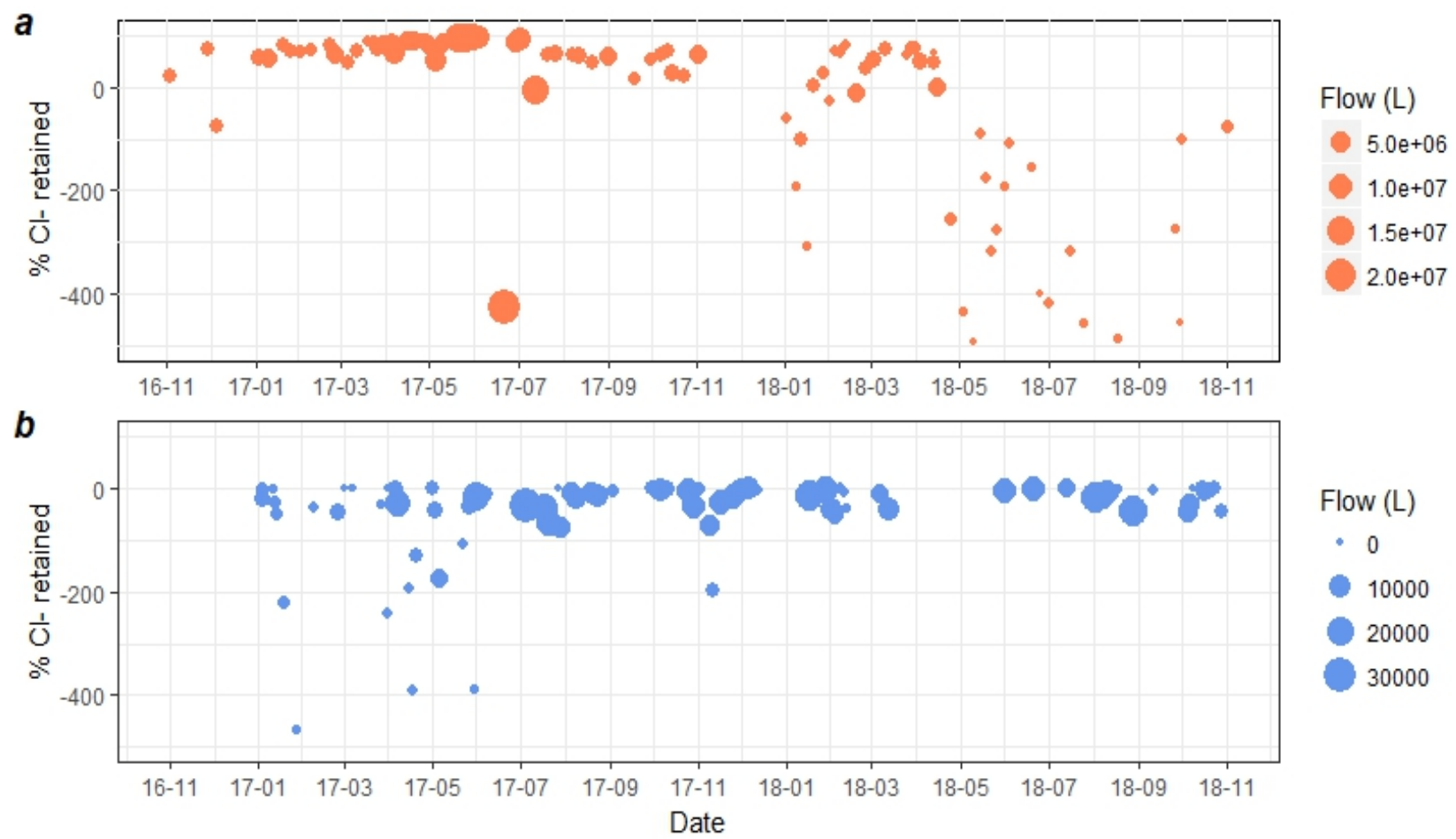

Figure 4. Percentage of $\mathrm{Cl}^{-}$retained by (a) $\mathrm{DH}$ and (b) OAK during rain and melt events in the 2 -year pond monitoring period $(\mathrm{n}=201)$. Note that negative retention indicates $\mathrm{Cl}^{-}$release.

\subsubsection{Event-Scale Cl- Retention}

DH and OAK behaved very differently in terms of event-scale $\mathrm{Cl}^{-}$retention (Figure 4). $\mathrm{DH}$ retained $\mathrm{Cl}^{-}$for 60 of 103 events (58\%) whereas $\mathrm{OAK}$ retained $\mathrm{Cl}^{-}$for 14 of the 81 events (17\%). OAK's Cl-releasing events occurred mostly in the spring of 2017, whereas $\mathrm{DH}^{\prime}$ 's $\mathrm{Cl}^{-}-$ releasing events occurred mostly in the summer of 2018. Some minimums in $\mathrm{Cl}^{-}$retention for both ponds exceed $-100 \%$ (i.e., release), indicating that melt events and large spring and summer rains may be flushing out $\mathrm{Cl}^{-}$retained in ponds over the winter season. This corresponds with watershed-level findings from Corsi et al. (2015) that streams receive heavily $\mathrm{Cl}^{-}$-laden water during low flow winter events, as well as high flow periods throughout the year. 
Total flow of an event does not correspond to $\mathrm{Cl}^{-}$retention; therefore, those melt and spring rain events must carry water with high $\mathrm{Cl}^{-}$concentrations. For $\mathrm{OAK}$ and $\mathrm{DH}, 49 \%$ and $55 \%$ of the total $\mathrm{Cl}^{-}$release occurred during events, respectively. This supports findings from Snodgrass et al. (2017) that SWMPs do not prevent high concentrations of $\mathrm{Cl}^{-}$from reaching streams.

\subsubsection{Stream Response to Pond $\mathrm{Cl}^{-}$Export}

The $\mathrm{Cl}^{-}$concentration response of the headwater stream receiving flow from the OAK pond is shown for the subset of the study period when in-stream conductivity sensors were deployed (Figure 5a). During the late summer of 2018, when stream volume was higher, the difference between upstream and downstream $\mathrm{Cl}^{-}$concentrations at $\mathrm{OAK}$ was relatively constant. Once the winter deicing season started in November 2018, the difference between upstream and downstream $\mathrm{Cl}^{-}$concentrations began to fluctuate. The peaks in upstream-downstream $\mathrm{Cl}^{-}$ concentration differences correspond to pulses of high $\mathrm{Cl}^{-}$export from the pond (Figure 5b).

Both upstream and downstream baseline $\mathrm{Cl}^{-}$concentrations increase over the monitoring

period, suggesting that sources upstream of the pond input are contributing to a slow increase of $\mathrm{Cl}^{-}$in the stream, and OAK is contributing to $\mathrm{Cl}^{-}$peaks (Figure 5a). Upstream of OAK is an area with 115 ha of residential land, 296 ha of agricultural or undifferentiated rural land, 5 stormwater management ponds, and a headwater creek that exceeds chronic CWQG for the protection of aquatic life (120 mg L $\left.\mathrm{m}^{-1}\right)$ almost year-round. Upstream $\mathrm{Cl}^{-}$concentrations exceeded chronic CWQG for $72 \%$ ( 21 weeks) of the stream monitoring period and exceeded acute guidelines (640 $\left.\mathrm{mg} \mathrm{L}^{-1}\right)$ for 3\% $\left(\sim 1\right.$ week) of the stream monitoring period. Comparatively, downstream $\mathrm{Cl}^{-}$ 
concentrations exceeded chronic guidelines for over $99 \%$ ( 30 weeks) of the stream monitoring period and exceeded acute guidelines for $6 \%$ ( 2 weeks $)$ of the stream monitoring period.

Summer stream $\mathrm{Cl}^{-}$concentrations above chronic guidelines may potentially be maintained by $\mathrm{Cl}^{-}$-laden groundwater discharge as well as stream outflows (Casey et al., 2013). It is likely that stream $\mathrm{Cl}^{-}$concentrations remain above the chronic guidelines year-round, suggesting that stream reaches that receive water from SWMPs are only hospitable to salttolerant biota. This may reflect a flaw in the design of bottom-draw ponds. The ponds were designed this way to protect coldwater habitat but are exporting highly saline water into receiving waters.
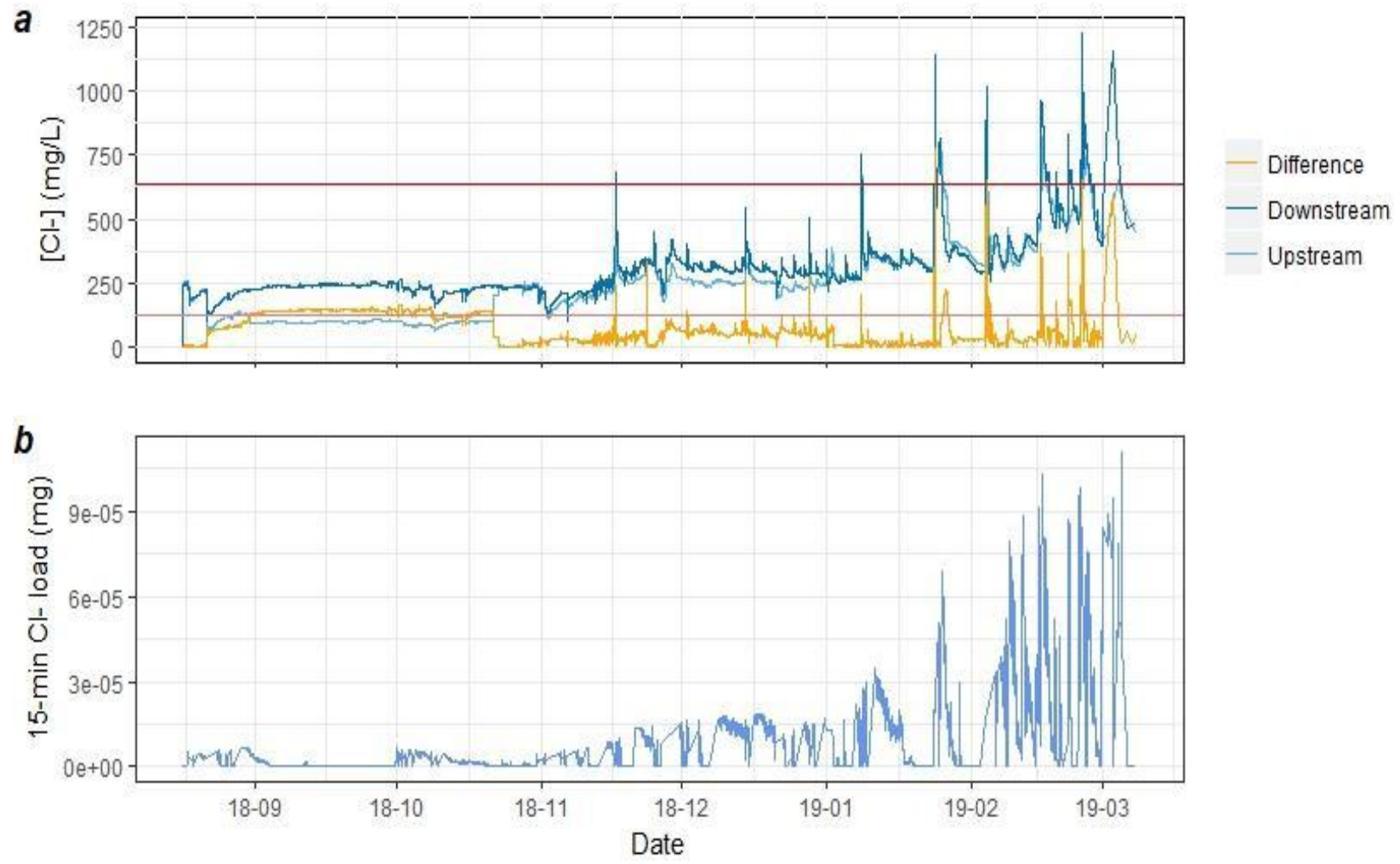

Figure 5. (a) Stream $\mathrm{Cl}^{-}$response to the pond outflow at OAK. Lower and upper lines represent chronic and acute CWQG for the protection of aquatic life, respectively. (b) The recorded mass of $\mathrm{Cl}^{-}$leaving OAK for each 15-minute interval in the stream monitoring period. 


\subsubsection{Implications for Understanding the Influence of SWMPs on Watershed-Scale $\mathrm{Cl}^{-}$ Retention and the Identification of SVAs}

This research shows that on an annual basis, one pond consistently retained $\mathrm{Cl}^{-}$, which suggests losses to groundwater. Future studies may incorporate several strategically chosen groundwater monitoring points to check for seepage. The other pond had variable annual retention; this may be in part due to limitations of our flow monitoring and study period, which may be biasing our findings regarding $\mathrm{Cl}^{-}$storage. Small changes in the level-to-flow relationship can result in large changes in the overall water balance of the pond. It would be helpful to have flow data for a longer period, such as the entire ice-free season. A longer study period would also help to elucidate patterns in water and $\mathrm{Cl}^{-}$retention; in this study, there were considerable fluctuations between Y17 and Y18, but we were unable to verify whether these were part of a longer-term pattern. It is likely that SWMPs play a role in watershed-scale $\mathrm{Cl}^{-}$ retention; however, further research is required to examine interannual variability, and to determine what factors influence the timing and magnitude of pond $\mathrm{Cl}^{-}$flushing.

The in-pond data suggest major flushing in the late spring and early summer months. We also observed that the receiving stream experienced pulses of $\mathrm{Cl}^{-}$-laden pond outflows throughout the winter. These data suggest that SWMPs concentrate diffuse salt inputs onto the landscape. Streams receiving pond outflows may be more vulnerable than adjacent areas; this suggests that SWMP locations should be considered in the identification of SVAs. Future studies could consider including more ponds that span a land-use gradient. If these ponds were also inline with streams, downstream impacts could be more accurately quantified. 


\subsection{Conclusions}

The application of deicing salts in watersheds that experience icy winters leads to watershed-scale $\mathrm{Cl}^{-}$retention and long-term elevated $\mathrm{Cl}^{-}$concentrations in surface and ground waters. SWMPs, a commonly used SCM, are known to impact pollutant transport, but $\mathrm{Cl}^{-}$ retention in SWMPs over different time scales was previously unclear. To better understand $\mathrm{Cl}^{-}$ retention in SWMPs, this study: (1) quantified the mass of $\mathrm{Cl}^{-}$entering and leaving two SWMPs through stormwater pipes; (2) determined annual, seasonal, and event-scale $\mathrm{Cl}^{-}$retention for the SWMPs using a mass balance approach; (3) compared changes in $\mathrm{Cl}^{-}$retention to in-pond $\mathrm{Cl}^{-}$ concentrations; and (4) quantified the response of a receiving stream to $\mathrm{Cl}^{-}$exported from one of the SWMPs.

Stormwater management pond behaviour can be unpredictable; ponds may consistently retain $\mathrm{Cl}^{-}$like $\mathrm{OAK}$, or alternately retain and release $\mathrm{Cl}^{-}$like $\mathrm{DH}$. However, high- $\mathrm{Cl}^{-}-$ concentration flushes dependably occur during spring melts and, to a lesser extent, during events throughout the year. The ponds do not prevent heavily $\mathrm{Cl}^{-}-$laden water from reaching streams and contribute to year-round inputs of $\mathrm{Cl}^{-}$to streams. As such, SWMPs deserve particular attention in $\mathrm{Cl}^{-}$transport models and geospatial models of SVAs in urbanizing watersheds, especially those with large areas drained by ponds. Further study is required to determine longterm patterns of $\mathrm{Cl}^{-}$retention in SWMPs and to determine the effects of different land uses on the efficacy of SWMPs for $\mathrm{Cl}^{-}$retention. 


\subsection{Acknowledgements}

We are grateful to Merrin Macrae and Janina Plach (University of Waterloo Faculty of Environment) for conducting the ion analyses, Chandler Eves (Lake Simcoe and Region Conservation Authority) for providing level, flow, and pond design data, Murray Richardson (Carleton University) for providing the HYSEP R code, Darko Joksimovic and Chris Wellen (Ryerson Urban Water) for their input on pond flow modelling and study design, Kayla Wong for providing catchment and impervious area data, and Arsh Grewal and Sarah Ariano for assistance obtaining field samples. This project was undertaken with the financial support of the Government of Canada through the federal Department of the Environment. This project was funded through an Environment and Climate Change Canada Lake Simcoe/South-Eastern Georgian Bay Clean-Up Fund Grant (GCXE16R024). 


\section{Summary}

Increasing urban development is accompanied by increasing impervious area and therefore, flashier stream hydrographs. This drives a need for stormwater control measures (SCM). Stormwater management ponds (SWMP) are a popular SCM in urbanizing watersheds and have some water quality benefits as well. However, in seasonally snowy and icy urban areas that receive deicing salts, they have been criticized as potentially promoting long-term storage and release of $\mathrm{Cl}^{-}$to receiving waterways. Given the ubiquity of SWMPs and the rising concentrations of $\mathrm{Cl}^{-}$in groundwater, rivers, and lakes that receive inputs from urban areas, a better understanding of $\mathrm{Cl}^{-}$retention in SWMPs over different time scales is needed.

This study aimed to quantify $\mathrm{Cl}^{-}$retention in 2 SWMPs in an urbanizing watershed using a mass balance approach and asses the impact of a SWMP on the receiving stream. We found that the SWMPs were unpredictable with respect to water and $\mathrm{Cl}^{-}$retention; one consistently retained $\mathrm{Cl}^{-}$, while the other retained $\mathrm{Cl}^{-}$in one year and released in the other. The SWMPs may be losing water and $\mathrm{Cl}^{-}$to groundwater and simultaneously releasing pulses of high-Cl-concentration water to surface waters. $\mathrm{Cl}^{-}$flushing from the SWMPs primarily occurred during the spring melt and large events throughout the year, indicating that the SWMPs are contributing to year-round inputs of $\mathrm{Cl}^{-}$to streams. However, water released via stormwater pipes from the ponds has lower $\mathrm{Cl}^{-}$concentrations that the water received. As such, SWMPs must be considered in $\mathrm{Cl}^{-}$transport models and geospatial models of SVAs in urbanizing watersheds. Further study is required to determine long-term patterns of $\mathrm{Cl}^{-}$retention in SWMPs and the drivers behind them. 


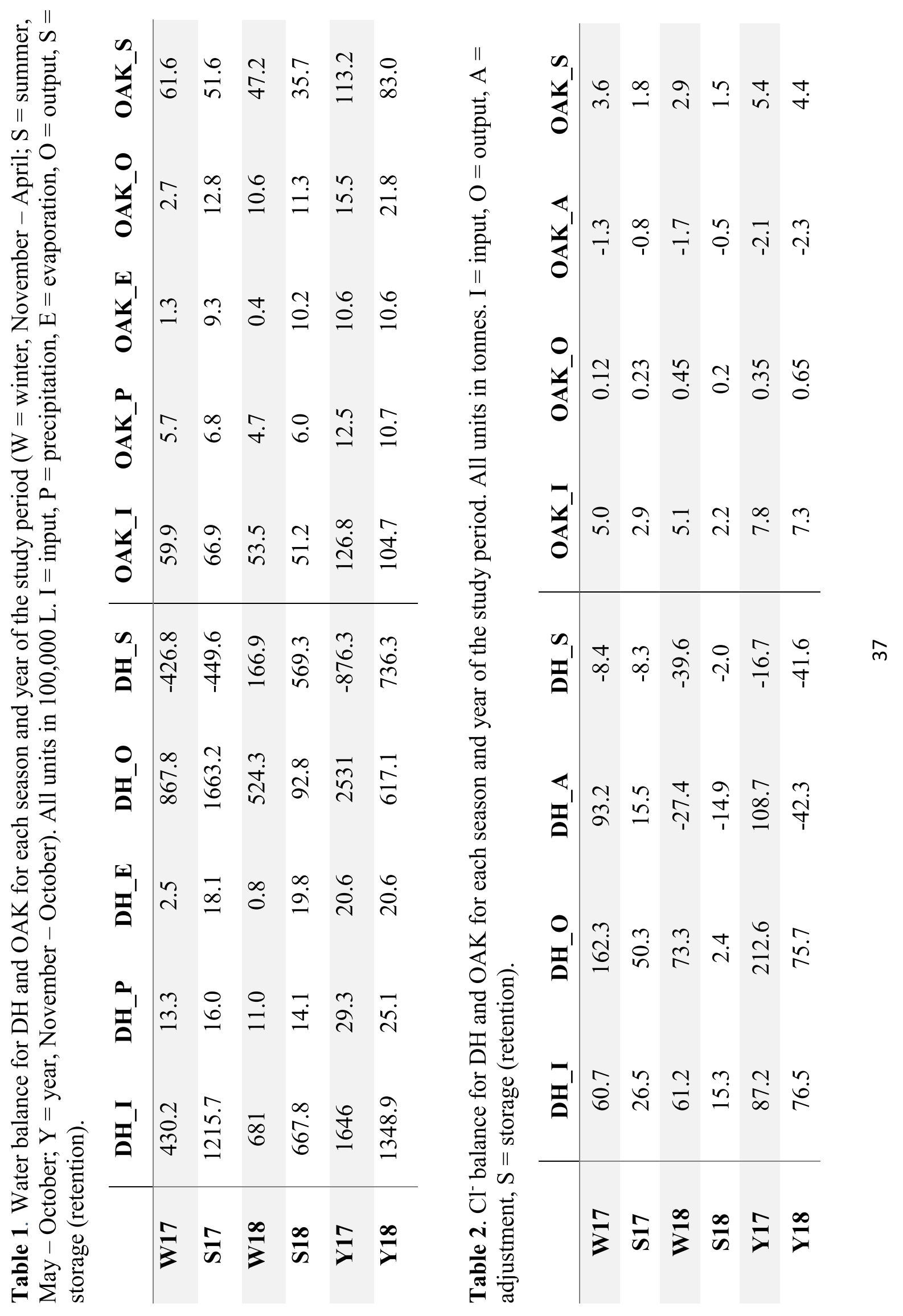



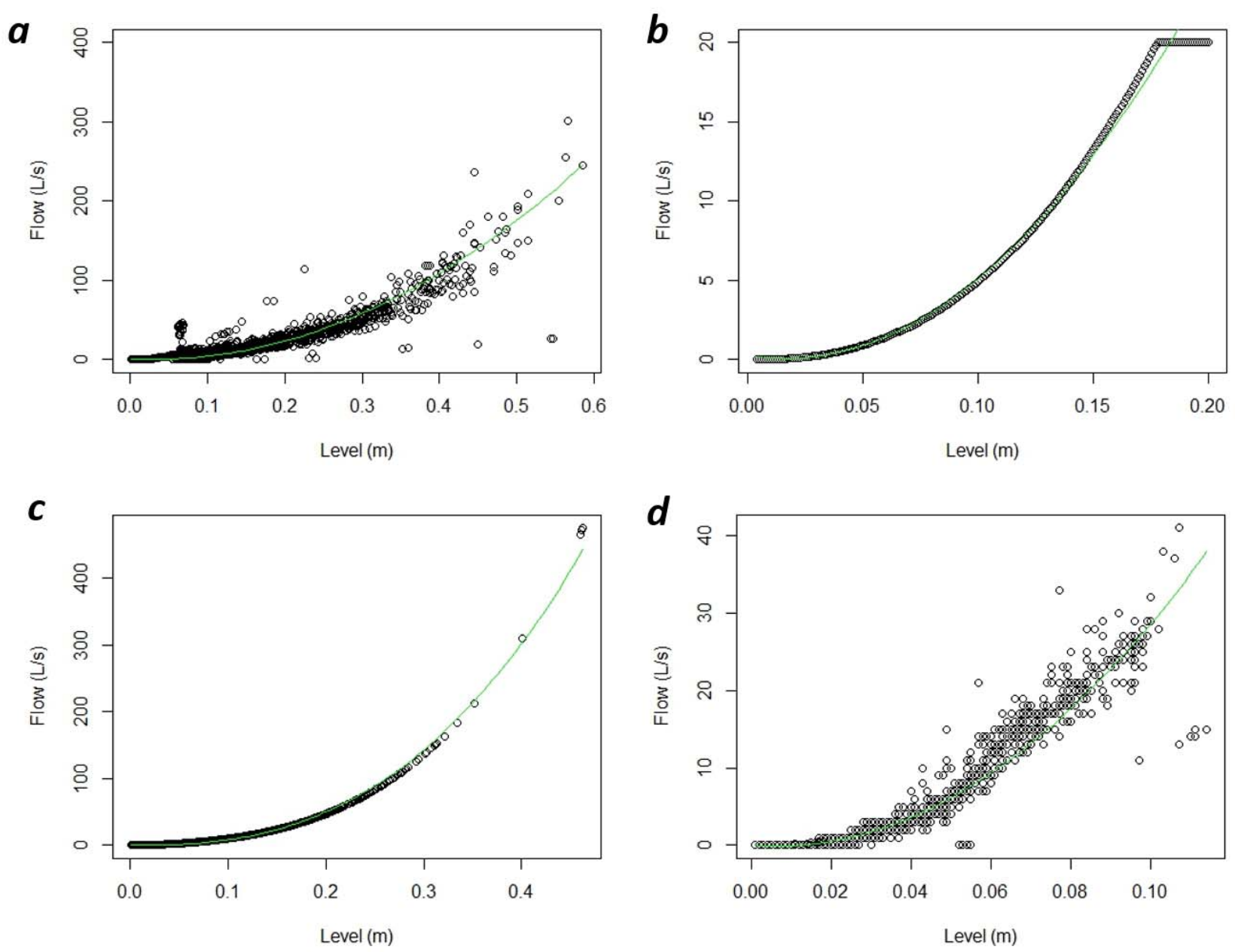

Figure 6. Level-to-flow plots for the (a) DH inflow $\left(\mathrm{R}^{2}=0.73\right)$, (b) DH outflow $\left(\mathrm{R}^{2}=0.99\right)$, (c) OAK inflow $\left(\mathrm{R}^{2}=0.99\right)$, and (d) OAK outflow $\left(\mathrm{R}^{2}=0.98\right)$. 


\section{References}

Anderson DG. 1970. Effects of Urban Development on Floods in Northern Virginia. United States Geological Survey

Arnone RD, Perdek Walling J. 2007. Waterborne pathogens in urban watersheds. Journal of Water and Health 5 (1): 149-162 DOI: 10.2166/wh.2006.001

Barbier L, Suaire R, Durickovic I, Laurent J, Simonnot MO. 2018. Is a Road Stormwater Retention Pond Able to Intercept Deicing Salt? Water, Air, and Soil Pollution 229 (8) DOI: $10.1007 /$ s1 1270-018-3908-9

Batroney T, Wadzuk BM, Traver RG. 2009. Parking Deck's First Flush. Journal of Hydrologic Engineering DOI: 10.1061/(asce)he.1943-5584.0000167

Bazinet NL, Gilbert BM, Wallace AM. 2010. A comparison of urbanization effects on stream benthic macroinvertebrates and water chemistry in an urban and an urbanizing basin in Southern Ontario, Canada. Water Quality Research Journal of Canada

Beeton AM. 1965. Eutrophication of the St. Lawrence Great Lakes. Limnology and Oceanography 10 (2): 240-254 DOI: 10.4319/lo.1965.10.2.0240

Bettez ND, Groffman PM. 2012. Denitrification potential in stormwater control structures and natural riparian zones in an urban landscape. Environmental Science and Technology 46 (20): 10909-10917 DOI: 10.1021/es301409z

Booth DB, Roy AH, Smith B, Capps K. 2016. Global perspectives on the urban stream syndrome. Journal of Freshwater Science 35 (1): 412-420 DOI: 10.1086/684940.

Bradford A, Gharabaghi B. 2004. Evolution of Ontario's stormwater management planning and design guidance. Water Quality Research Journal of Canada

Brilly M. 2007. Local Flood Defence Systems in Europe. In Advances in Urban Flood Management Taylor \& Francis; 321-338. DOI: 10.1201/9780203945988.ch14

Brown AH, Yan ND. 2015. Food Quantity Affects the Sensitivity of Daphnia to Road Salt. Environmental Science \& Technology 49 (7): 4673-4680 DOI: 10.1021/es5061534

Bubeck RC, Diment WH, Deck BL, Baldwin AL, Lipton SD. 1971. Runoff of Deicing Salt: Effect on Irondequoit Bay, Rochester, New York. Science 172 (3988): 1128-1132 DOI: 10.1126/science.172.3988.1128

Casey RE, Lev SM, Snodgrass JW. 2013. Stormwater ponds as a source of long-term surface and ground water salinisation. Urban Water Journal 10 (3): 145-153 DOI: 10.1080/1573062X.2012.716070

CCME. 2011. Canadian Water Quality Guidelines for the Protection of Aquatic Life: CHLORIDE. Canadian environmental quality guidelines Available at: http://ceqgrcqe.ccme.ca/download/en/337 
Chapra SC, Dove A, Rockwell DC. 2009. Great Lakes chloride trends: Long-term mass balance and loading analysis. Journal of Great Lakes Research 35 (2): 272-284 DOI:

10.1016/j.jglr.2008.11.013

Chow VT. 1965. Handbook of applied hydrology. International Association of Scientific Hydrology Bulletin DOI: 10.1080/02626666509493376

Cooper CA, Mayer PM, Faulkner BR. 2014. Effects of road salts on groundwater and surface water dynamics of sodium and chloride in an urban restored stream. Biogeochemistry 121 (1): 149-166 DOI: 10.1007/s10533-014-9968-Z

Corsi SR, De Cicco LA, Lutz MA, Hirsch RM. 2015. River chloride trends in snow-affected urban watersheds: increasing concentrations outpace urban growth rate and are common among all seasons. Science of The Total Environment 508: 488-497 DOI: 10.1016/j.scitotenv.2014.12.012

Corsi SR, Graczyk DJ, Geis SW, Booth NL, Richards KD. 2010. A fresh look at road salt: Aquatic toxicity and water quality impacts on local, regional, and national scales. Environmental Science \& Technology 44 (19): 7376-7382 DOI: 10.1021/es101333u

Crowther RA, Hynes HBN. 1977. The effect of road deicing salt on the drift of stream benthos. Environmental Pollution (1970) 14 (2): 113-126 DOI: 10.1016/0013-9327(77)90103-3

Daley ML, Potter JD, McDowell WH. 2009. Salinization of urbanizing New Hampshire streams and groundwater: effects of road salt and hydrologic variability. Journal of the North American Benthological Society 28 (4): 929-940 DOI: 10.1899/09-052.1

Davis AP, McCuen RH. 2005. Stormwater Management for Smart Growth. Springer-Verlag: New York. DOI: 10.1007/0-387-27593-2

Davis JC. 1975. Minimal dissolved oxygen requirements of aquatic life with emphasis on Canadian species: A review. Journal of the Fisheries Research Board of Canada 32 (12): 2295-2332 DOI: 10.1139/f75-268

Diment WH, Bubeck RC, Deck BL. 1973. Some effects of deicing salts on Irondequoit Bay and its drainage basin. Highway Research Record 425: 23-35

Douglas I. 2015. The analysis of cities as ecosystems. In The Routledge Handbook of Urban Ecology. DOI: 10.4324/9780203839263.ch2

Duan S, Newcomer-Johnson T, Mayer P, Kaushal S. 2016. Phosphorus retention in stormwater control structures across streamflow in urban and suburban watersheds. Water (Switzerland) 8 (9) DOI: 10.3390/w8090390

Dugan HA, Bartlett SL, Burke SM, Doubek JP, Krivak-Tetley FE, Skaff NK, Summers JC, Farrell KJ, McCullough IM, Morales-Williams AM, et al. 2017. Salting our freshwater lakes. Proceedings of the National Academy of Sciences 114 (17): 4453-4458 DOI: 10.1073/pnas. 1620211114

Dupuis D, Sprague E, Docherty KM, Koretsky CM. 2019. The influence of road salt on seasonal mixing, redox stratification and methane concentrations in urban kettle lakes. Science of the Total Environment 661 DOI: 10.1016/j.scitotenv.2019.01.191 
Earle S. 2015. Physical Geology. BCcampus: Victoria, BC.

Egemose S, Sønderup MJ, Grudinina A, Hansen AS, Flindt MR. 2015. Heavy metal composition in stormwater and retention in ponds dependent on pond age, design and catchment type. Environmental technology 36 (5-8): 959-969 DOI: 10.1080/09593330.2014.970584

Ehrenfeld JG, Palta M, Stander E. 2015. Wetlands in urban environments. In The Routledge Handbook of Urban EcologyRoutledge. DOI: 10.4324/9780203839263.ch27

Environment Canada. 2018. Code of practice: Road salts environmental management.

Environment Canada. 2019. Historical Climate Data. Available at: http://climate.weather.gc.ca/

Fellenberg G. 2000. The Chemistry of Pollution. Wiley and Sons, Ltd.: Chichester, UK.

Fletcher TD, Andrieu H, Hamel P. 2013. Understanding, management and modelling of urban hydrology and its consequences for receiving waters: A state of the art. Advances in Water Resources DOI: 10.1016/j.advwatres.2012.09.001

Gallagher MT, Snodgrass JW, Ownby DR, Brand AB, Casey RE, Lev S. 2011. Watershed-scale analysis of pollutant distributions in stormwater management ponds. Urban Ecosystems 14 (3): 469-484 DOI: 10.1007/s11252-011-0162-y

GHD. 2017. Parking lot design guidelines to promote salt reduction (Report \#2-11115623). Lake Simcoe Region Conservation Authority: Newmarket, Canada.

Gold AC, Thompson SP, Piehler MF. 2017. Water quality before and after watershed-scale implementation of stormwater wet ponds in the coastal plain. Ecological Engineering 105: 240-251 DOI: 10.1016/j.ecoleng.2017.05.003

Gray SR, Becker NSC. 2002. Contaminant flows in urban residential water systems. Urban Water 4 (4): 331-346 DOI: 10.1016/S1462-0758(02)00033-X

Gutchess K, Jin L, Lautz L, Shaw SB, Zhou X, Lu Z. 2016. Chloride sources in urban and rural headwater catchments, central New York. Science of The Total Environment 565: 462-472 DOI: $10.1016 /$ j.scitotenv.2016.04.181

Hassall C, Anderson S. 2015. Stormwater ponds can contain comparable biodiversity to unmanaged wetlands in urban areas. Hydrobiologia 745 (1): 137-149 DOI:

$10.1007 / \mathrm{s} 10750-014-2100-5$

Higashino M, Erickson AJ, Toledo-Cossu FL, Beauvais SW, Stefan HG. 2017. Rinsing of saline water from road salt in a sandy soil by infiltrating rainfall: Experiments, simulations, and implications. Water, Air, and Soil Pollution DOI: 10.1007/s11270-017-3256-1

Hill AR, Sadowski EK. 2016. Chloride concentrations in wetlands along a rural to urban land use gradient. Wetlands DOI: 10.1007/s13157-015-0717-4

Hintz WD, Relyea RA. 2019. A review of the species, community, and ecosystem impacts of road salt salinisation in fresh waters. Freshwater Biology 64 (6): 1081-1097 DOI: 10.1111/fwb.13286

Hintz WD, Mattes BM, Schuler MS, Jones DK, Stoler AB, Lind L, Relyea RA. 2017. 
Salinization triggers a trophic cascade in experimental freshwater communities with varying food-chain length. Ecological Applications 27 (3): 833-844 DOI: 10.1002/eap.1487

Houck MC. 2015. In livable cities is preservation of the wild. In The Routledge Handbook of Urban EcologyRoutledge. DOI: 10.4324/9780203839263.ch5

Howard KWF, Haynes J. 1993. Groundwater contamination due to road de-icing chemicals - salt balance implications. Geoscience Canada

Howard KWF, Maier H. 2007. Road de-icing salt as a potential constraint on urban growth in the Greater Toronto Area, Canada. Journal of Contaminant Hydrology 91 (1-2): 146-170 DOI: 10.1016/j.jconhyd.2006.10.005

Hubbart JA, Kellner E, Hooper LW, Zeiger S. 2017. Quantifying loading, toxic concentrations, and systemic persistence of chloride in a contemporary mixed-land-use watershed using an experimental watershed approach. Science of the Total Environment 581-582: 822-832 DOI: $10.1016 /$ j.scitotenv.2017.01.019

Huling EE, Hollocher TC. 1972. Groundwater contamination by road salt: Steady-state concentrations in East Central Massachusetts. Science 176 (4032): 288-290 DOI: $10.1126 /$ science. 176.4032 .288

James MB, Dymond RL. 2011. Bioretention hydrologic performance in an urban stormwater network. Journal of Hydrologic Engineering DOI: 10.1061/(asce)he.1943-5584.0000448

Jones EL, Hastie GD, Smout S, Onoufriou J, Merchant ND, Brookes KL, Thompson D. 2017. Seals and shipping: Quantifying population risk and individual exposure to vessel noise. Journal of Applied Ecology DOI: 10.1111/1365-2664.12911

Judd JH. 1970. Lake stratification caused by runoff from street deicing. Water Research 4 (8): 521-532 DOI: 10.1016/0043-1354(70)90002-3

Karraker NE, Gibbs JP, Vonesh JR. 2008. Impacts of road deicing salt on the demography of vernal pool-breeding amphibians. Ecological Applications 18 (3): 724-734 DOI: $10.1890 / 07-1644.1$

Kaushal SS. 2016. Increased salinization decreases safe drinking water. Environmental Science \& Technology 50 (6): 2765-2766 DOI: 10.1021/acs.est.6b00679

Kaushal SS, Delaney-Newcomb K, Findlay SEG, Newcomer TA, Duan S, Pennino MJ, Sivirichi GM, Sides-Raley AM, Walbridge MR, Belt KT. 2014. Longitudinal patterns in carbon and nitrogen fluxes and stream metabolism along an urban watershed continuum.

Biogeochemistry 121 (1): 23-44 DOI: 10.1007/s10533-014-9979-9

Kaushal SS, Groffman PM, Likens GE, Belt KT, Stack WP, Kelly VR, Band LE, Fisher GT. 2005. From The Cover: Increased salinization of fresh water in the northeastern United States. Proceedings of the National Academy of Sciences 102 (38): 13517-13520 DOI: 10.1073/pnas.0506414102

Kelly VR, Findlay SE, Hamilton SK, Lovett GM, Weathers KC. 2019. Seasonal and long-term dynamics in stream water sodium chloride concentrations and the effectiveness of road salt Best Management Practices. Water, Air, \& Soil Pollution 230 (1): 13 DOI: 10.1007/s11270- 


\section{8-4060-2}

Kelly VR, Lovett GM, Weathers KC, Findlay SEG, Strayer DL, Burns DJ, Likens GE. 2008. Long-term sodium chloride retention in a rural watershed: Legacy effects of road salt on streamwater concentration. Environmental Science and Technology 42 (2): 410-415 DOI: $10.1021 / \mathrm{es} 0713911$

Kilgour BW, Gharabaghi B, Perera N. 2014. Ecological benefit of the road salt code of practice. Water Quality Research Journal 49 (1): 43-52 DOI: 10.2166/wqrjc.2013.129

Kincaid DW, Findlay SEG. 2009. Sources of elevated chloride in local streams: groundwater and soils as potential reservoirs. Water, Air, and Soil Pollution 203 (1-4): 335-342 DOI: $10.1007 / \mathrm{s} 11270-009-0016-\mathrm{x}$

Kunkle SH. 1972. Effects of road salt on a Vermont stream. Journal of the American Water Works Association 64 (5): 290-295 DOI: 10.1002/j.1551-8833.1972.tb02694.x

Labashosky S. 2015. The salty truth: Revealing the need for stricter road salt application and storage regulations in the United States. 26 (1)

Lax SM, Peterson EW, Van der Hoven SJ. 2017. Stream chloride concentrations as a function of land use: a comparison of an agricultural watershed to an urban agricultural watershed. Environmental Earth Sciences 76 (20): 1-12 DOI: 10.1007/s12665-017-7059-x

Likens GE, Buso DC. 2010. Salinization of Mirror Lake by Road Salt. Water, Air, and Soil Pollution 205 (1-4): 205-214 DOI: 10.1007/s11270-009-0066-0

Löfgren S. 2001. The chemical effects of deicing salt on soil and stream water of five catchments in southeast Sweden. Water, Air, and Soil Pollution 130 (1): 863-868 DOI: 10.1023/A:1013895215558

LSRCA. 2011. 2010 Stormwater pond maintenance and anoxic conditions investigations (Final Report). Lake Simcoe Region Conservation Authority: Newmarket, Canada.

Maltby L, Forrow DM, Boxall ABA, Calow P, Betton CI. 1995. The effects of motorway runoff on freshwater ecosystems: 1. Field study. Environmental Toxicology and Chemistry 14 (6): 1079-1092 DOI: 10.1002/etc.5620140620

Marsalek J. 2003. Road salts in urban stormwater: an emerging issue in stormwater management in cold climates. Water Science and Technology 48 (9): 61-70 DOI: 10.2166/wst.2003.0493

Marsalek J, Karamouz M, Goldenfum J, Chocat B. 2006. Urban water cycle processes and interactions. International Hydrological Programme of United Nations Educational, Scientific, and Cultural Organization (UNESCO) (78): 131

Maxted J, Shaver E. 1997. The use of retention basins to mitigate stormwater impacts on aquatic life. In Effects of Watershed Development and Management on Aquatic Ecosystems; Proceedigs of an Engineering Foundation Conference.

Mayer T, Snodgrass WJ, Morin D. 1999. Spatial characterization of the occurrence of road salts and their environmental concentrations as chlorides in Canadian surface waters and benthic sediments. Water Quality Research Journal of Canada 
Meierdiercks KL, Smith JA, Baeck ML, Miller AJ. 2010a. Heterogeneity of hydrologic response in urban watersheds. Journal of the American Water Resources Association DOI: 10.1111/j.1752-1688.2010.00487.x

Meierdiercks KL, Smith JA, Baeck ML, Miller AJ. 2010b. Analyses of urban drainage network structure and its impact on hydrologic response. Journal of the American Water Resources Association DOI: 10.1111/j.1752-1688.2010.00465.x

Meriano M, Eyles N, Howard KWF. 2009. Hydrogeological impacts of road salt from Canada's busiest highway on a Lake Ontario watershed (Frenchman's Bay) and lagoon, City of Pickering. Journal of Contaminant Hydrology 107 (1-2): 66-81 DOI: 10.1016/j.jconhyd.2009.04.002

Van Meter RJ, Swan CM. 2014. Road salts as environmental constraints in urban pond food webs. PLoS ONE 9 (2) DOI: 10.1371/journal.pone.0090168

Mitchell VG, Mein RG, McMahon TA. 2001. Modelling the urban water cycle. Environmental Modelling \& Software 16 (7): 615-629 DOI: 10.1016/S1364-8152(01)00029-9

Moore TLC, Hunt WF. 2012. Ecosystem service provision by stormwater wetlands and ponds A means for evaluation? Water Research 46 (20): 6811-6823 DOI:

10.1016/j.watres.2011.11.026

Müller B, Gächter R. 2012. Increasing chloride concentrations in Lake Constance: characterization of sources and estimation of loads. Aquatic Sciences 74 (1): 101-112 DOI: 10.1007/s00027-011-0200-0

Newcomer Johnson TA, Kaushal SS, Mayer PM, Grese MM. 2014. Effects of stormwater management and stream restoration on watershed nitrogen retention. Biogeochemistry 121 (1): 81-106 DOI: 10.1007/s10533-014-9999-5

Norrström A., Jacks G. 1998. Concentration and fractionation of heavy metals in roadside soils receiving de-icing salts. Science of The Total Environment 218 (2-3): 161-174 DOI: 10.1016/S0048-9697(98)00203-4

Novotny E V., Murphy D, Stefan HG. 2008. Increase of urban lake salinity by road deicing salt. Science of The Total Environment 406 (1-2): 131-144 DOI: 10.1016/j.scitotenv.2008.07.037

Novotny EV, Stefan HG. 2010. Projections of chloride concentrations in urban lakes receiving road de-icing salt. Water, Air, and Soil Pollution 211 (1-4): 261-271 DOI: 10.1007/s11270009-0297-0

O’Connor EM, McConnell C, Lembke D, Palmer ME, Stainsby EA, Winter JG. 2012. Annual water balances, total phosphorus budgets and total nitrogen and chloride loads to Lake Simcoe (2004-2007). Lake Simcoe Region Conservation Authority: Newmarket, Canada.

Ontario Ministry of the Environment, Conservation and P. 2017. Guidelines on snow disposal and de-icing operations in Ontario. Queen's Printer for Ontario: Ottawa, Canada.

Ontario Ministry of the Environment. 2003. Stormwater management planning and design manual. Queen's Printer for Ontario: Ottawa, Canada. 
Oswald CJ, Giberson G, Nicholls E, Wellen C, Oni S. 2019. Spatial distribution and extent of urban land cover control watershed-scale chloride retention. Science of the Total Environment 652: 278-288 DOI: 10.1016/j.scitotenv.2018.10.242

Panno S V., Hackley KC, Hwang HH, Greenberg SE, Krapac IG, Landsberger S, O’Kelly DJ. 2006. Characterization and identification of $\mathrm{Na}-\mathrm{Cl}$ sources in ground water. Ground Water DOI: $10.1111 / \mathrm{j} .1745-6584.2005 .00127 . \mathrm{x}$

Paul MJ, Meyer JL. 2001. Streams in the urban landscape. Annual Review of Ecology and Systematics 32: 333-365 DOI: doi:10.1146/annurev.ecolsys.32.081501.114040

Pennino MJ, McDonald RI, Jaffe PR. 2016. Watershed-scale impacts of stormwater green infrastructure on hydrology, nutrient fluxes, and combined sewer overflows in the midAtlantic region. Science of The Total Environment 565: 1044-1053 DOI: 10.1016/j.scitotenv.2016.05.101

Perera N, Gharabaghi B, Noehammer P, Kilgour B. 2010. Road salt application in Highland Creek watershed, Toronto, Ontario - Chloride mass balance. Water Quality Research Journal 45 (4): 451-461 DOI: 10.2166/wqrj.2010.044

R Core Team. 2017. R: A language and environment for statistical computing. $R$ Foundation for Statistical Computing, Vienna, Austria

Robinson HK, Hasenmueller EA, Chambers LG. 2017. Soil as a reservoir for road salt retention leading to its gradual release to groundwater. Applied Geochemistry 83: 72-85 DOI: 10.1016/j.apgeochem.2017.01.018

Rooney RC, Foote L, Krogman N, Pattison JK, Wilson MJ, Bayley SE. 2015. Replacing natural wetlands with stormwater management facilities: Biophysical and perceived social values. Water Research DOI: 10.1016/j.watres.2014.12.035

Sauer VB, Thomas WO, Stricker VA, Wilson K V. 1983. Flood characteristics of urban watersheds in the United States DOI: 10.3133/wsp2207

Schuler MS, Relyea RA. 2018. A review of the combined threats of road salts and heavy metals to freshwater systems. BioScience 68 (5): 327-335 DOI: 10.1093/biosci/biy018

Schwartz D, Sample DJ, Grizzard TJ. 2017. Evaluating the performance of a retrofitted stormwater wet pond for treatment of urban runoff. Environmental Monitoring and Assessment 189 (6) DOI: 10.1007/s10661-017-5930-6

Searle CL, Shaw CL, Hunsberger KK, Prado M, Duffy MA. 2016. Salinization decreases population densities of the freshwater crustacean, Daphnia dentifera. Hydrobiologia 770 (1) DOI: $10.1007 / \mathrm{s} 10750-015-2579-4$

Sherwood WC. 1989. Chloride loading in the South Fork of the Shenandoah River, Virginia, U.S.A. Environmental Geology and Water Sciences DOI: 10.1007/BF01728501

Sibert RJ, Koretsky CM, Wyman DA. 2015. Cultural meromixis: Effects of road salt on the chemical stratification of an urban kettle lake. Chemical Geology 395: 126-137 DOI: 10.1016/j.chemgeo.2014.12.010 
Sloto RA, Crouse MY. 1996. HYSEP: A computer program for streamflow hydrograph separation and analysis. DOI: 10.3133/wri964040

Soller J, Stephenson J, Olivieri K, Downing J, Olivieri AW. 2005. Evaluation of seasonal scale first flush pollutant loading and implications for urban runoff management. Journal of Environmental Management 76 (4): 309-318 DOI: 10.1016/j.jenvman.2004.12.007

Swinton MW, Eichler LW, Boylen CW. 2015. Road salt application differentially threatens water resources in Lake George, New York. Lake and Reservoir Management 31 (1): 20-30 DOI: $10.1080 / 10402381.2014 .983583$

TAC. 2013. Syntheses of best practices road salt management: Salt management plans. Transportation Association of Canada: Ottawa, Canada.

Thornthwaite CW, Holzman B. 1939. The determination of evaporation from land and water surfaces. Monthly Weather Review 67 (1): 4-11 DOI: 10.1175/15200493(1939)67<4:TDOEFL>2.0.CO;2

Thunqvist E-L. 2004. Regional increase of mean chloride concentration in water due to the application of deicing salt. The Science of the total environment 325 (1-3): 29-37 DOI: 10.1016/j.scitotenv.2003.11.020

Todd AK, Kaltenecker MG. 2012. Warm season chloride concentrations in stream habitats of freshwater mussel species at risk. Environmental Pollution 171: 199-206 DOI: 10.1016/j.envpol.2012.07.040

Town of Aurora. 2010. Official Plan DOI: 10.1002/ajmg.a.34366

Town of Newmarket. 2014. Official Plan: 2006-2026

TRCA. 2012. Stormwater management criteria version 1. Toronto and Region Conservation Authority: Toronto, Canada.

Tyree M, Clay N, Polaskey S, Entrekin S. 2016. Salt in our streams: even small sodium additions can have negative effects on detritivores. Hydrobiologia 775 (1): 109-122 DOI: $10.1007 / \mathrm{s} 10750-016-2718-6$

United States Environmental Protection Agency(USEPA). 2011. Estimating Change in Impervious Area (IA) and Directly Connected Impervious Areas (DCIA) for Massachusetts Small MS4 Permit. US Environmental Protection Agency (April): 1-5

United States Environmental Protection Agency(USEPA). 2016. Quick guide to drinking water sample collection

Vengosh A, Pankratov I. 1998. Chloride/bromide and chloride/fluoride ratios of domestic sewage effluents and associated contaminated ground water. Ground Water DOI: 10.1111/j.1745-6584.1998.tb02200.x

Wallace AM, Biastoch RG. 2016. Detecting changes in the benthic invertebrate community in response to increasing chloride in streams in Toronto, Canada. Freshwater Science 35 (1): 353-363 DOI: 10.1086/685297

Walsh CJ, Webb JA. 2016. Interactive effects of urban stormwater drainage, land clearance, and 
flow regime on stream macroinvertebrate assemblages across a large metropolitan region. Freshwater Science 35 (March 2016): 324-339 DOI: 10.1086/685105.

Walsh CJ, Fletcher TD, Burns MJ. 2012. Urban Stormwater Runoff: A New Class of Environmental Flow Problem. PLoS ONE 7 (9) DOI: 10.1371/journal.pone.0045814

Walsh CJ, Roy AH, Feminella JW, Cottingham PD, Groffman PM, Morgan RP. 2005. The urban stream syndrome: current knowledge and the search for a cure. Journal of the North American Benthological Society 24 (3): 706-723 DOI: 10.1899/04-028.1

White C. 2000. Spatial and temporal variations in critical loads for rivers in N.E. Scotland: a validation of approaches. Water Research 34 (6): 1912-1918 DOI: 10.1016/S00431354(99)00340-1

Williams DD, Williams NE, Cao Y. 2000. Road salt contamination of groundwater in a major metropolitan area and development of a biological index to monitor its impact. Water Research 34 (1): 127-138 DOI: 10.1016/S0043-1354(99)00129-3

Winter JG, Landre A, Lembcke D, O'Connor EM, Young JD. 2011. Increasing chloride concentrations in Lake Simcoe and its tributaries. Water Quality Research Journal of Canada 46 (2): 157-165 DOI: 10.2166/wqrjc.2011.124 
